\title{
Literatura
}

\section{jako spotkanie z człowiekiem. Profesora Jacka Brzozowskiego wspominają Jego przyjaciele i współpracownicy z łódzkiej polonistyki}

Barbara Stelmaszczyk: Pamiętam Jacka ${ }^{1}$ jeszcze z czasu jego studiów. Byłam wtedy od niedawna zatrudniona w Katedrze Historii Literatury Uniwersytetu Łódzkiego na etacie asystenta-stażysty. Nam, stażystom, wypadło prowadzić zajęcia $\mathrm{z}$ warsztatu bibliograficznego, ale prowadziłam też (z większą przyjemnością) ćwiczenia z romantyzmu. Mówię o tym dlatego, że miałam zajęcia z grupami z roku Jacka. To byli ludzie trochę starsi wiekiem niż zazwyczaj studenci pierwszoroczni. Wiem, że albo przyszli z jakichś innych kierunków, albo po ukończeniu dwuletniego Studium Nauczycielskiego.

Krystyna Pietrych: Jacek z politechniki...

BS: Tak. Grupa Jacka była interesująca, może również ze względu na fakt, że należały do niej osoby już z pewnym doświadczeniem studiowania i bardziej świadome dokonanego wyboru kierunku. Jacek wyraźnie zaznaczał swą obecność, uczestnicząc w moich zajęciach z romantyzmu. Pisał referat

${ }^{1}$ Prof. dr hab. Jacek Brzozowski (1951-2017), historyk literatury, znawca twórczości epoki romantyzmu oraz poezji współczesnej. Współautor (obok prof. Zbigniewa Przychodniaka) nowego wydania krytycznego dzieł Juliusza Słowackiego. W latach 2002-2005 prodziekan Wydziału Filologicznego UŁ ds. studiów filologii polskiej, bibliotekoznawstwa, kulturoznawstwa i filologii słowiańskiej. Kierownik Zakładu Poezji XIX i XX wieku Katedry Literatury Romantyzmu, Dwudziestolecia Międzywojennego i Literatury Współczesnej (2003-2007), a od 2008 roku - kierownik Katedry Literatury i Tradycji Romantyzmu UŁ. 
- nie pamiętam już, na jaki temat. Pamiętam za to jego wielkie skupienie, kiedy czytał ten referat na zajęciach. I tak myślę o Jacku, odkąd go poznałam, zawsze bardzo skupiał się na tym, co robił, i bardzo to przeżywał. Gdy czytał referat, świat dookolny mu znikał. Był w tym interesujący, dobry. Potem wyjechałam z Polski i moje zajęcia ze studentami się urwały. Chyba tuż po studiach Jacek pojechał na staż do IBL-u. Potem znałam go już jako asystenta pani profesor Heleny Karwackiej ${ }^{2}$ i mojego uniwersyteckiego kolegę. Wówczas profesor Karwacka otrzymała etaty chyba dla czterech osób. Wśród nich byli Jacek, Stefan Tomaszewski ${ }^{3}$, Alicja Skalska ${ }^{4}$.

Maria Berkan-Jabłońska: Jacek zaczął pracę zaraz po studiach jako asystent w katedrze profesor Heleny Karwackiej?

Tomasz Cieślak: Wtedy nie było katedry romantyzmu, lecz dwie czy trzy katedry historii literatury.

BS: Były: Katedra Historii Literatury i Katedra Teorii Literatury. Tę pierwszą prowadził profesor Zdzisław Skwarczyński ${ }^{5}$, a katedrę teorii - profesor Stefania Skwarczyńska ${ }^{6}$. Dopiero później nastąpiło wyodrębnienie katedr historycznoliterackich wedle prowadzonych $w$ nich badań nad poszczególnymi

2 Prof. dr hab. Helena Karwacka, w latach 1954-1979 związana z Uniwersytetem Łódzkim. Tutaj w roku 1969 uzyskała habilitację - na podstawie książki Witold Wandurski (1968), a w 1977 otrzymała tytuł profesorski - na podstawie monografii Artur Glisczyński, pieśniarz fabrycznej Łodzi (1975). Od roku 1972 pełniła funkcję prodziekana Wydziału Filologicznego. W 1974 objęła kierownictwo Zakładu Literatury Współczesnej. Autorka blisko dwustu prac: szkiców, esejów i recenzji, w tym pięciu książek. Do Jej osiągnięć badawczych należą prace o Jerzym Żuławskim, Witoldzie Wandurskim, Arturze Glisczyńskim, Andrzeju Strugu i Władysławie Broniewskim, liczne szkice i artykuły (także popularnonaukowe) poświęcone tradycji teatralnej i kulturze literackiej Łodzi, a także książka o kabarecie Momus (1982).

${ }^{3}$ Dr Stefan Tomaszewski (ur. 1949), pracownik łódzkiej polonistyki od roku 1975, zatrudniony początkowo w Zakładzie Literatury Współczesnej. Od 1981 roku w zespole Katedry Literatury Romantyzmu i Literatury Współczesnej UŁ - jako asystent, a następnie adiunkt. Stopień doktora uzyskał na podstawie rozprawy Postacie miejskich plebejuszy w prozie polskiej okresu międzypowstaniowego (1831-63). Od roku 2003 pracował Katedrze Literatury Romantyzmu, Dwudziestolecia Międzywojennego i Literatury Współczesnej UŁ, a od 2007 - w Katedrze Literatury XX i XXI wieku UŁ jako starszy wykładowca. W roku 2014 przeszedł na emeryturę.

${ }^{4}$ Alicja Skalska z d. Nitecka (ur. 1952), polonistka, absolwentka UŁ. Obecnie pracownik Studium Języka Polskiego dla Cudzoziemców UŁ.

${ }^{5}$ Prof. dr Zdzisław Skwarczyński (1914-1987), filolog, specjalista z zakresu literatury oświecenia, zajmował się również późnym klasycyzmem warszawskim i wileńskim, a także wybranymi zagadnieniami literatury XX wieku. Studia polonistyczne odbył na UW. Od 1945 roku związany z UŁ na stanowisku asystenta; od 1971 profesor UŁ; prodziekan (19521953) i dziekan (1953-1955) Wydziału Filologicznego UŁ, prorektor UŁ ds. nauczania (19681969), rektor UŁ (1969-1972). Dyrektor Instytutu Filologii Polskiej UŁ w latach 1970-1978. Redaktor naczelny „Prac Polonistycznych” w latach 1958-1959 i 1970-1983.

${ }^{6}$ Prof. dr hab. Stefania Skwarczyńska (1902-1988), współorganizatorka UŁ. W 1937 roku na podstawie monografii Teoria listu otrzymała pierwszą w Polsce habilitację z dziedziny teorii literatury. Zainicjowała wydawanie pisma "Zagadnienia Rodzajów Literackich". Od kwietnia do października 1973 roku dyrektor Instytutu Teorii Literatury, Teatru i Filmu. 
epokami literackimi. Gdy zaś jeszcze później odeszła profesor Karwacka, to do Katedry Literatury Romantyzmu pani profesor Krystyny Poklewskiej ${ }^{7}$ przyłączono tymczasowo pod jej opiekę zespół pracowników dawnej katedry profesor Karwackiej. W ten sposób staliśmy się z Jackiem kolegami we wspólnej katedrze. Powiększony zespół okazał się współpracować świetnie i z dobrymi wynikami. Okazał się też trwały, a katedra zyskała nazwę Literatury Romantyzmu i Literatury Współczesnej...

KP: ...w tym czasie profesor Karwacka odeszła do Warszawy, a potem do Białegostoku.

MB-J: Czy Jacek pisał pracę magisterską jeszcze u profesor Karwackiej?

KP: Tak: Rodzaje i funkcje mitów w twórczości Tadeusza Różewicza. Potem jej wariant został opublikowany w roku 1977 w "Pracach Polonistycznych”, pod tytułem O symbolizmie środka i tragicznej wizji świata w twórczości Tadeusza Różewicza. Można ten artykuł uznać za debiut naukowy Jacka.

MB-J: W 1978 roku pojechał do Warszawy, do IBL-u?

KP: Tak, i był tam do roku 1980. To lata stażu w IBL-u. Jacek chętnie wracał do swojej pracy nad motywem muz, którą wtedy rozpoczął. O Różewiczu też później mówił często, ale rzadziej wspominał swoje magisterium. Moglibyśmy do niego dotrzeć, bo jest zapewne w archiwum.

TC: Miałem z Jackiem zajęcia z romantyzmu na drugim roku studiów, w 1986 roku. Mówisz, Basiu, o skupieniu i gorliwości... Byłem chyba w całkowicie żeńskim towarzystwie na tych ćwiczeniach. Koleżanki bardzo je przeżywały, ponieważ Jacek bardzo angażował się w to, co mówił. Mam wracające wspomnienie: nasza rozmowa na zajęciach, która przerodziła się w mój spór z Jackiem, o jedno słowo w Fantazym Słowackiego. Już nie pamiętam, jakie to było słowo. Jacek odczytywał mi tę frazę i pytał: „Czy pan nie słyszy, że tu jest ironia?”. Ja mówię: „Jest kpina”. „Niech pan posłucha jeszcze raz". I tak cztery czy pięć razy. Nie wychodziliśmy poza ten cytat. W pewnym momencie podciągnął bardzo wysoko spodnie, zarzucił nogę na nogę, usiadł na biurku i mówi: „No nie!”. „Ale ja naprawdę nie słyszę...”.

${ }^{7}$ Prof. dr hab. Krystyna Poklewska (ur. 1933), historyk literatury polskiej. Prace na UŁ rozpoczęła w roku 1959, a rok później debiutowała artykułem Recepcja Stowackiego we Lwowie (1852-1870), ogłoszonym w "Zeszytach Naukowych Uniwersytetu Łódzkiego". Pełniła funkcję prodziekana Wydziału Filologicznego ds. studiów zaocznych (1975-1978), była wicedyrektorem Instytutu Filologii Polskiej oraz kierownikiem Zakładu Współczesnej Literatury Polskiej (1979-1981). Po rozwiązaniu Instytutu w 1981 roku kierowała Katedrą Literatury Romantyzmu i Literatury Współczesnej (do 2003 roku) oraz sprawowała funkcję pełnomocnika dziekana ds. dydaktyki na wydziale polonistyki (1981-1995). Badaczka literatury polskiej XIX wieku, autorka m.in. rozpraw: Galicja romantyczna (1816-1840) (1976), Aleksander Fredro (1977), Krew na śniegu. Rzecz o rabacji galicyjskiej w literaturze polskiej (1986), O Mickiewiczu i Stowackim. Cztery szkice (1999, współautor: J. Brzozowski). 
Koleżanka próbowała nas pogodzić: „Może tu jest coś pomiędzy?”. A Jacek: „E, pomiędzy!". Do czego zmierzam? Kiedy zostałem zatrudniony jako asystent, zdałem sobie sprawę, że gdy rozmawiałem z Jackiem na temat różnych moich artykułów - zresztą to zawsze Jacek inicjował te rozmowy, bo nigdy nie miałem odwagi iść do niego i zapytać, co myśli o moim tekście, chyba że to była rozmowa na zebraniu katedry - on nieustająco podkreślał, że należy przyglądać się drobiazgom. Przypominam sobie mój szkic na temat wiersza Wata. Myśmy wtedy wspólnie, w dość szerokim gronie, przygotowywali książkę interpretacyjną, Jacek robił też językową i edytorską korektę. Tego się bałem, mówiąc szczerze. Zadzwoniłem wtedy w jakiejś innej sprawie do Jacka, a on mówi niby od niechcenia: „Słuchaj, właśnie skończyłem robić Twój tekst. Zwróć uwagę na jeszcze jedną rzecz...". To była kwestia symboliki obrazu. Po trzech - czterech dniach musiałem wysłać mu zupełnie inną wersję artykułu, bo mi to wszystko poprzestawiało. Nie powiedział przecież: „Poszedłeś złą drogą, jak tego nie uwzględnisz, to nic z tego nie będzie". Skoro więc mówimy o angażowaniu się Jacka, to właśnie było tak: niezwykle dociekliwie, ale zawsze delikatnie. Jeśli ktoś chce przyjść, przyjąć poradę, proszę, ale jak nie - to nie.

MB-J: Nie miałam szczęścia znać Jacka ze studiów. Nie miałam z nim ani zajęć, ani wykładu. Spotkaliśmy się dopiero, gdy był recenzentem mojej pracy magisterskiej. Wcześniej bardzo mnie peszył. Widywałam go na korytarzu na trzecim piętrze w naszym starym budynku, wydawał mi się taki wielki, raptowny, głośny. To wszystko bardzo mnie deprymowało. Same studia doktoranckie wspominam wspaniale. Ale i wtedy przyglądałam się Jackowi jako znacznie starszemu koledze, który nadal paraliżował erudycją, swobodą wypowiedzi, pewnością sądów. Powiem wam, że lody między mną a Jackiem przełamały się dopiero wtedy, kiedy zaproponował mi pracę i kiedy tę pracę podjęłam. A dał mi warunek trudny, zapytał: „Czy będziesz odtąd zajmować się romantyzmem?", którym się przecież nie zajmowałam. Na początku często siedzieliśmy obok siebie w gabinecie, nie bardzo wiedząc, jak rozmawiać, aż pewnego dnia Jacek wrócił ze swojego wykładu. Jak to on, opowiadał o romantyzmie całym sobą. Podałam mu karteczkę, którą znalazłam na drzwiach: „Kocham profesora Brzozowskiego". Jacek, uradowany i trochę mile podłechtany, wykrzyknął bez zastanowienia: „Powiem Ewie!”" . I zaczęliśmy się śmiać. Tych momentów będzie mi brakować: gdy Jacek po wykładzie zaglądał do mnie i opowiadał, jak było. Jeszcze raz wszystko przeżywał.

KP: Moje wspomnienia związane z Jackiem są znacznie późniejsze niż wasze. Natomiast w tym, co mówił Tomek, pojawiło się coś, co nazwałabym walką Jacka o to, żeby przekonać do tego, co jest zasadniczo - jego ulubione słowo - ważne. Mówię o tym, żeby zwrócić uwagę, że dla niego istotna, również w tym, co pisał, była perswazyjna strona kontaktu z odbiorcą. Chodziło o to,

\footnotetext{
${ }^{8}$ Ewa Brzozowska, żona Jacka Brzozowskiego (zmarła w 2011 roku).
} 
żeby przekonać nie tyle i nie tylko - i w ogóle: nie przede wszystkim - do kwestii estetycznych, tylko żeby przekonać do czegoś, co on bardzo często nazywał "prawdą literatury”. A dla niego ta prawda literatury sytuowała się gdzieś na pograniczu literatury i życia, literatury i egzystencji - dlatego to, czy w tamtej frazie była kpina, czy ironia, miało dla niego tak duże znaczenie, bo wykraczało poza tekst. I budowało się $\mathrm{w}$ przestrzeni pomiędzy tekstem a odbiorem, czyli czytelnikiem - osobą. Wydaje mi się, że ta cecha personalnego kontaktu z literaturą pozostawała dla Jacka szalenie ważna. Po tamtej stronie jest osoba, czyli autor - nie nadawca komunikatu, nie odpersonalizowany twór - i po drugiej stronie - żeby w ogóle coś istotnego zaistniało - też jest osoba. Osoba, która widzi albo kpinę, albo ironię. To nie jest niuans i dlatego on nie mógł się zgodzić na to zażegnanie sporu zatarciem różnic „a może pomiędzy". Nie ma "pomiędzy". Są dwie osoby i nie ma "pomiędzy”. Jest w tym coś ekstremalnego. Jacek taki był, pomimo swej łagodności.

MB-J: Zachowywał w sobie otwartość na dialog, dyskusję. Niedawno, kiedy wydawał różne swoje rozproszone teksty poświęcone interpretacjom wierszy, w przedmowie napisał, że chciałby po prostu przedstawić te utwory, które były i nadal są dla niego ważne. To pokazuje, że literaturę postrzegał jako nieodłączną część życia, była mu do czegoś potrzebna - po to, żeby odpowiadać sobie na pewne istotne pytania, nie z powodów estetycznych.

TC: Na przykład jego czytanie Liryków lozańskich, jego powroty do nich.

BS: Oprócz tego, że miał swoją twardą postawę badawczą - również umiał uważnie słuchać. I gdy był przekonany, przyjmował uwagi rozmówców. Pamiętam zebranie naukowe $\mathrm{w}$ katedrze pani profesor Poklewskiej, przed jego habilitacją. Mówił o którymś z Mickiewiczowskich sonetów. Czytał swój szkic i wywiązała się interesująca dyskusja autora ze słuchaczami, jej plon uwzględnił potem w pewnej mierze w swoim tekście. Potrafił słuchać i potrzebował rozmów o literaturze. Miał umysł analityczny, chętnie poświęcał uwagę interpretacjom wierszy. I tu, przy okazji, dygresja o moich spacerach $\mathrm{z}$ Jackiem do Łagiewnik. Była $\mathrm{w}$ nim pasja związana $\mathrm{z}$ literaturą i jego wewnętrzną postawą badawczą. Przyjeżdżał do mnie na rowerze, zostawialiśmy ten rower w moim mieszkaniu. Czasem był sam, czasem ze swoim synkiem Konradem. Wsiadaliśmy do mojego małego fiata i jechaliśmy do Łagiewnik, żeby na leśnych ścieżkach rozmawiać o literaturze. A Jacek, kiedy zaczynał mówić, stawał się tak zaangażowany, że (jak to już sygnalizowałam) tracił z oczu dookolny świat. Do tego stopnia, że któregoś razu nagle stwierdziliśmy, że nie ma Konrada. Myśmy się strasznie zagadali, a to dziecko było arcygrzeczne i nie protestowało, nie marudziło i nie żądało głośno, by poświęcić mu uwagę. Nagle więc zobaczyliśmy, że daleko od nas, z tyłu, siedzi na ścieżce i płacze. Do dziś sobie to wyrzucam. Jacek miał potrzebę, by rozmawiać o literaturze także poza uniwersytetem, poza zajęciami, zebraniami naukowymi. Kiedyś dyskutowaliśmy bardzo żywiołowo. Zadałam mu 
wtedy pytanie wyłonione z kategorii wyobrażeń ekstremalnych i zapytałam: "Gdybyś miał do wyboru albo zamknięte pokoje z książkami - i nic z natury, albo tylko natura i bez książek - to co byś wybrał?". Pomyślał dłuższą chwilę i powiedział: „Zamknięte pokoje”. Oczywiście, pytanie było trochę głupie, bo wymuszało wybór bezwzględny, niemniej ten wybór wydał mi się charakterystyczny i wiele mówiący o pasji Jacka dla literatury.

Lidia Ignaczak: Ale myślę, że teoretyczny i nieostateczny, nieakategoryczny. Przypomina mi się jego refleksja na temat Paryża. Pojechał tam, wrócił - a Paryż to było moje wielkie marzenie, więc pytałam go o wrażenia. Jacek mówił: „Kamiennie-pustynnie, tam nie ma drzew!”. Chodziło mu o to, że to miejsce okazało się inne niż utrwalone $\mathrm{w}$ imaginacji poprzez lektury. Inne, niż sobie wyobrażał, i to zderzenie z realnością tak podziałało...

BS: W Paryżu jest dużo drzew, tylko poczucie obcości mogło tak zadziałać...

LI: Jego wrażenie sprowadzało się do kamienności, same domy... Myślę, że odczuwał potrzebę otwartości, zieleni.

BS: Masz rację, przecież ciągle jeździł w góry i zawsze się tam spotykaliśmy.

KP: I, co istotne, na wrzesień - miesiąc, w którym rozmawiamy - planował kolejny wyjazd, który nie nastąpił.

MB-J: Dlatego zgadzam się, że odpowiedź „zamknięte pokoje” była chwilowa...

LI: Ale prawdziwa $\mathrm{w}$ danej chwili, bo on był cały $\mathrm{w}$ danym momencie dla tego rozmówcy, z którym był.

MB-J: Czasem jednak z lekkim przekąsem wypowiadał się o takim modelu uprawiania nauki, który polegałby na całkowitym odizolowaniu się od świata i istnieniu wyłącznie przez pracę i literaturę. Nie było to dla niego możliwe do przyjęcia.

KP: Ekstremum-ekstremum. To się zmieniało w czasie, to nie było constans. Potrzeba bycia $w$ literaturze, poprzez literaturę, z biegiem czasu słabła. Nie, żeby w ogóle znikała, bo to niemożliwe, ale on coraz bardziej doświadczał ogromnej wartości bycia z konkretnymi ludźmi, na przykład wnukami - miał z nimi szalenie silną relację i niesłychanie dla niego ważną.

MB-J: Ona na pewno na nowo go określała. Promieniał, gdy mówił o wnukach.

KP: Tak, i nigdy nie usłyszałam od Jacka na przykład słów: „Szkoda, że w związku z tym nie mam czasu na przeczytanie czegoś". Kontakt z wnukami zawsze był pierwszoplanowy. Były najgłębszą potrzebą. 
BS: Razu pewnego byliśmy sami w katedrze, przyszłam jako druga, Jacek mówi: „Wyobraź sobie, że Gucio powiedział mi: «Nie pojadę z tobą samochodem, bo ty źle prowadzisz!»". Jacek był zszokowany, a podszyte to było lękiem, że Gucio rzeczywiście z nim nie pojedzie.

Jerzy Wiśniewski: Pozwólcie, że dopowiem, jak rozumiem ten Jackowy wybór zamkniętego pomieszczenia z książkami. Odczytywałbym to jako ówczesną deklarację erudyty - kogoś, kto znajduje wielką radość, wielką frajdę $\mathrm{w}$ studiowaniu rzeczy przeróżnych i porządkowaniu ich $\mathrm{w}$ sobie. Moje pierwsze wrażenie z kontaktu z Jackiem było właśnie takie, że mam do czynienia z erudytą - z człowiekiem na pewno niezwykłym, ale i nieco przytłaczającym swoją wiedzą, oczytaniem. To było w tym samym czasie, kiedy zajęcia z Jackiem miał Tomek, w 1986 roku. Mój studencki rocznik - i tym samym rocznik Krysi - nie miał do czynienia z Jackiem na ćwiczeniach z romantyzmu. Pamiętam jednak, że ktoś taki, bliżej nam nieznany, pojawiał się przy drzwiach gabinetu profesor Poklewskiej. Zajęcia z romantyzmu prowadziłaś ty, Basiu, i Nina Zielakowa9. Kiedy kończyłem studia, profesor Jerzy Poradecki ${ }^{10}$ organizował spotkania dotyczące ciekawych książek i różnych wydarzeń kulturalnych. W 1986 roku nowością wydawniczą był Odrzucony obraz C.S. Lewisa. Brałem udział w spotkaniu, na które został zaproszony przez pana profesora Jacek. I stałem się świadkiem niezwykle interesującej rozmowy dwóch erudytów na temat tej książki. Rozmowy, w której obaj swobodnie odwoływali się do dzieł literatury powszechnej, wtedy zupełnie mi nieznanych. Miałem wrażenie kontaktu z kimś, kto dysponuje ogromną wiedzą - nie tylko literacką, ale i tą kontekstualną - konieczną, żeby w wierszu docenić drobiazg, żeby go zauważyć. Bez kontekstu ten szczegół nie zostałby rozpoznany, może zostałby zauważony z jakichś względów stylistycznych, retorycznych, ale nie zostałby doceniony jako element godny interpretacyjnego drążenia i modyfikowania pierwotnego widzenia danego utworu. Tak pamiętam Jacka z pierwszego spotkania. A następne były na seminariach katedry pani profesor Poklewskiej. Wydaje mi się, że też uczestniczyłem w tym zebraniu, podczas którego była mowa o Sonetach krymskich. I to było kolejne oblicze Jacka: znakomitego interpretatora, doceniającego szczegół i potrafiącego płomiennie, ostro się spierać,

${ }^{9}$ Dr Janina Zielak z d. Lasecka. Pracownik łódzkiej polonistyki od 1975 roku. Od 1981 roku w zespole Katedry Literatury Romantyzmu i Literatury Współczesnej UŁ zatrudniona jako asystent, a następnie adiunkt; od roku 2003 - w Katedrze Literatury i Tradycji Romantyzmu UŁ jako starszy wykładowca. Badaczka literatury romantyzmu polskiego i jej recepcji, wiele uwagi poświęciła również takim zagadnieniom, jak Litwa romantyków, dramaturgia Szekspira i jej współczesne adaptacje. Autorka m.in. pracy Powieść poetycka w Polsce w okresie romantyzmu, Wrocław 1990. Przeszła na emeryturę w roku 2013.

${ }^{10}$ Prof. dr hab. Jerzy Poradecki (1942-2008), historyk literatury polskiej (w szczególności dwudziestowiecznej poezji), krytyk, wydawca. Pracownik UŁ od 1965 roku, kierownik Katedry Literatury Polskiej XX i XXI wieku od lutego 2008 roku. Autor m.in. książek: Pisarstwo Wilhelma Macha (1984), Aż tu moje skrzydło siega. Studium o dziejach motywu lotu poety w poezji polskiej (1988), Orfeusz poetów XX wieku (1995), Prorocy i sztukmistrze. Eseje o poezji polskiej XX wieku (1999). W ostatnich latach życia pracował nad Zbiorem poetów Łodzi i ziemi łódzkiej. 
i bronić tej prawdy, o czym, Krysiu, mówiłaś. Zawsze uważnie obserwowałem jego interpretacyjne poczynania. Mogę śmiało powiedzieć, że uczyłem się od niego czytania pojedynczych wierszy.

LI: To ja jeszcze o roku 1986. Owszem, dbałość o szczegól, ale też dystans i świetne poczucie humoru! Chyba nie Jacek, a Krysia Ratajska ${ }^{11}$ zadbała o to, żeby mnie włączyć do Towarzystwa Mickiewiczowskiego jako skarbnika. Wypadła wtedy sesja jubileuszowa, organizowana we Wrocławiu, i pojawiło się pytanie, kto ma na nią pojechać. Pojechał Jurek Poradecki, jako przewodniczący, Jacek i ja. $Z$ tego wyjazdu zostały mi w pamięci takie dwie migawki. Osobą, która narzuciła ton narracji wyprawie, był Jurek Poradecki, on dużo mówił. Jacek milczał. Nie było tego Jacka pohukującego, nadekspresyjnego. To był wykład estetyczny Jurka Poradeckiego, o wszystkim. Chodziliśmy po Wrocławiu, było bardzo miło. Organizatorzy zaprosili nas też, żebyśmy obejrzeli Panoramę Racławicką, poszliśmy. Komentarz Jacka zostanie mi na zawsze, wszedł, omiótł wzrokiem rotundę i powiedział: „Dużo tego!". Drugi moment, z Auli Leopoldina, gdzie, jak pamiętacie, są bardzo niewygodne ławy. Nie sięgałam stopami podłogi - to bardzo Jacka rozbawiło. I wtedy profesor Konrad Górski wszedł na katedrę, żeby wygłosić wykład - wszedł i usiadł. Myśmy go nie widzieli - ja już w ogóle, Jacek trochę. Rozbawiony powiedział: „Opowiem ci, co tam się dzieje”. W gruncie rzeczy to działo się równolegle: wykładowcy wykładali, a Jacek dokładał swój komentarz.

TC: Chciałbym wrócić do erudycji, łącząc to ze szczegółem, o którym wspomniała Marysia. Wydaje mi się, że jeśli ktoś nie znał Jacka i pomyśli o nim jako o erudycie, to może rozumieć to w sposób "tradycyjno-historycznoliteracki". A Jacek nie był erudytą encyklopedycznym. Jego erudycja była taka - nie wiem, jak to nazwać - „nieuczesana”. Myślę tutaj oczywiście o kompetencjach, dzięki którym mógł sobie pozwolić na wielopiętrowe skojarzenia. Pamiętam moje przerażenie, kiedy czytałem pierwszy fragment swojego doktoratu na temat Leśmiana. Przedstawiłem go wcześniej profesor Alinie Kowalczykowej ${ }^{12}$ i generalnie byłem $z$ tego tekstu zadowolony, a Jacek $\mathrm{w}$ trakcie zebrania dorzucił mi piętnaście, a może dwadzieścia, najprzeróżniejszych skojarzeń. Wyszedłem przybity. Profesor Kowalczykowa mówi:

${ }^{11}$ Prof. dr hab. Krystyna Ratajska (1938-2017), profesor Uniwersytetu Łódzkiego, badaczka recepcji biografii i twórczości Adama Mickiewicza oraz skamandrytów. Pracownik UŁ w latach 1973-2008. Do 2003 roku zatrudniona w Zakładzie Dydaktyki Języka Polskiego, następnie (2003-2008) kierownik Pracowni Literatury i Tradycji Romantyzmu. Autorka, m.in. prac: Dziedzice filomatyzmu (1987), Neomesjanistyczni spadkobiercy Mickiewicza (1998), Kraj młodości szczęśliwy. Śladami Juliana Tuwima po Łodzi i Inowłodzu (2002), O mariażu bukieciarstwa z poezja. Do źródeł „Kwiatów polskich” Juliana Tuwima (2007).

${ }^{12}$ Prof. dr hab. Alina Kowalczykowa (ur. 1936), historyk literatury polskiej XIX i XX wieku. Pracowała na łódzkiej polonistyce w latach 1982-1997. Autorka m.in. prac: Programy i spory literackie w dwudziestoleciu. 1918-1939 (1978), Warszawa romantyczna (1987), Piłsudski i tradycja (1991), Stowacki (1994), Romantyzm. Nowe spojrzenie (2008), Świadectwo autoportretu (2008). 
"Ty się tym nie przejmuj, Jacek tak zawsze ma”. Potem z nim rozmawiałem, przyznał: „Wiadomo, że przeszarżowałem, ale to trzeba sprawdzić”. I, oczywiście, zacząłem sprawdzać, prosząc go o różne podpowiedzi, większość tych rzeczy odpadła. To były pierwsze pomysły - wtedy się teksty czytało na zebraniach, nie dając ich wcześniej do wglądu.

MB-J: Jurek mówił o książce Lewisa Odrzucony obraz. Pamiętam rozmowę nieco późniejszą o projekcie wykładów z romantyzmu. Jacek wspominał, że jego dawne wykłady wyglądały inaczej niż obecnie również dlatego, że odbiorcy byli inni, odmienne były ich oczekiwania i kompetencje. Dlatego mógł, kreśląc podstawy myśli romantycznej, śmiało i swobodnie odwoływać się między innymi do Lewisa, Melville'a, Mertona, ks. Hellera, Manna; sięgać do najstarszych teorii epistemologicznych, do pierwszych nowożytnych koncepcji astronomicznych. To pokazuje też rodzaj skojarzeń, którymi się posługiwał. Z odległej przeszłości wydobywał różne zjawiska dokonane i obmyślane, odkrywając $\mathrm{w}$ nich zalążki pewnego procesu, który z wielką pasją chciał pokazać studentom. Ale też w romantyzmie widział źródła całkiem nowoczesnego i nurtującego go poczucia braku domu, przeczucia ciemności - i próbował o tym opowiadać. Krążenie wokół ważnych dla niego utworów i doświadczeń kulturowych przekładało się na porządek wykładowy. To była swobodna gra wyobraźni, poparta zarazem bardzo wnikliwym przeżyciem pewnych faktów lub lektur.

TC: I było to bardzo własne, a nie zapośredniczone z jakiejś bibliografii przedmiotowej. Pamiętam taką sytuację: kontekstowo potrzebowałem jakiegoś artykułu, Jacek sam mi go podpowiedział, nie wskazując dokładnie, gdzie mogę go znaleźć - tyle że w „Pamiętniku Literackim” kilkanaście lat wcześniej. Powiedział: „Daj spokój, nie szukaj, idź do Pana Jurka Rozenta$\mathrm{la}^{13}$, on na pewno pamięta". Powiedział to z lekkim przekąsem: nie trzeba pamiętać adresu bibliograficznego - ważne, żeby pamiętać, co tam było.

\section{LI: Lubił myśleć, prawda?}

KP: I przeżywać. Wydaje mi się, że to wszystko, o czym mówimy, układa się w obraz, który w nas jest żywy. Kiedy mówimy o jego erudycji, to widać, że ona była emocjonalno-żywiołowa. Ale chciałam teraz powiedzieć o drugiej stronie tej żywiołowości. W związku z naszymi przygotowaniami do sesji Leśmianowskiej wzięłam $\mathrm{z}$ archiwum Jacka dwie teczki, na których jest napisane „Leśmian”. Jakiś miesiąc przed śmiercią mówił mi, że chciałby wziąc udział w tej konferencji. Wyjęłam te teczki, żeby zobaczyć, czy nie zaczął nad czymś pracować, czy nie ma tam czegoś, co moglibyśmy jakoś

${ }^{13}$ Dr Jerzy Rozental (1930-1998), językoznawca, teoretyk literatury. Pracownik UŁ w latach 1957-1995, najpierw Zakładu Literatury Polskiej XIX wieku, a następnie Katedry Teorii Literatury; od 1988 roku - zatrudniony w Katedrze Literatury Romantyzmu i Literatury Współczesnej UŁ. Przeszedł na emeryturę w 1995 roku. 
odtworzyć i zaprezentować. Kiedy je przeglądałam, zobaczyłam, że zaczął wykonywać gigantyczną pracę. Nie wiem, kiedy. Pracę jeszcze nieukierunkowaną. W tych teczkach jest kilkadziesiąt stron jego nie-notatek, tylko wypisów z Leśmiana, które są podporządkowane tematom, na przykład „Leśmian - śmierć, pogrzeb, grób”, „Leśmian - las”, dużo wypisów z listów. Miniantologia Leśmiana. Przepisywał, nie wiedział jeszcze dokładnie po co. Chodzi mi o taki gest, który jest coraz rzadszy - gest bezinteresowności. Pamiętam, kiedy na zajęciach ze studentami mówiłam, że bardzo ważne jest dla mnie przepisanie wiersza. Widziałam wtedy szczególnego rodzaju zainteresowanie połączone $\mathrm{z}$ pewną troską - oto wykonuję pewne działania na poły magiczne, właściwie niepotrzebne. A tu „Leśmian - szkice”, ,Leśmian - dąbrowa, dęby". Znalazłam też coś, co mnie poruszyło - „Materiały do szkicu o otchłani". Wydaje mi się, że Jacek nigdy takiego szkicu nie napisał. Coś się tam zaczyna. To są materiały głównie wypisowe, ale jest kilka zdań Jacka, które były początkiem nowego myślenia. Rzecz jest na tyle staranna, że jeśli znalazł literówkę, to ją poprawił. Jego żarliwość miała swój rewers, który nie do końca był nam znany: takiej bardzo spokojnej pracy, polegającej na myśleniu, bliskim kontakcie $\mathrm{z}$ tekstem poprzez przepisywanie. Wydaje się, że jeśli ktoś jest żarliwy, to wystarczy mu iskra - i już. A mnie się zdaje, że ta iskra pojawiała się na bardzo stabilnym gruncie, do którego nie mieliśmy dostępu.

TC: O tego typu pracy Jacek w ogóle nie mówił. Zresztą zauważcie, że on nigdy też nie mówił - a przynajmniej ja nie słyszałem - o swoich próbach warsztatowych.

JW: Tak, przychodził z gotowym tekstem.

TC: Nigdy nie mówił, że czegoś nie dokończył. To znaczy mówił, że jest w trakcie - „dalej nie pytaj”. Ale co miał zrobić, to było jego wewnętrzną sprawą.

JW: Chociaż pamiętam, że przy okazji którejś konferencji, jakieś dwadzieścia parę lat temu, powiedział: "Ja muszę napisać to jeszcze raz, wyszło nie tak, jest za długie, trzeba z większą dyscypliną". Czasem się odsłaniał, ale to były pojedyncze zdania.

TC: Kiedy zbliżał się termin którejś naszej katedralnej konferencji, a byłem w proszku i mówiłem mu o tym, on odpowiedział, że też jeszcze nie napisał tekstu. Traktowałem to jako rodzaj pocieszenia z jego strony - po prostu mu nie wierzyłem.

Przemysław Dakowicz: Ale tak było. Profesor wiele razy pisał w ostatniej chwili. Wszyscy zdajemy sobie sprawę, że takie "prędkie" tworzenie wartościowych tekstów naukowych nie jest możliwe bez uprzedniej wieloletniej 
pracy intelektualnej, która materiał badawczy porządkuje, hierarchizuje, nadaje mu określony kształt.

MB-J: Chciałabym zwrócić uwagę na to, że Jacek dysponował - wszyscy o tym wiemy - taką swoją, wyrazistą dykcją, nie tylko mówienia, ale i pisania. Kiedy czyta się jego teksty, one są natychmiast rozpoznawalne: określone frazy, sformułowania, składnia. To jest Jacek. Dziś zdarza się bardzo rzadko, że mamy w nauce do czynienia z osobowościami o tak wyrazistej, rozpoznawalnej dykcji. Jest jeszcze jedna rzecz, którą chciałabym podkreślić, à propos tej niechęci do mówienia o warsztacie, o pisaniu. Jacek był bardzo skromny. Jego artykuły miały szczególne tytuły: Szkice, Notatki do lektury, O kilku szczegółach..., Glosy do wiersza..., Na marginesie... To jest sedno Jackowego pisania. Kryje się w nim pokora człowieka, który naprawdę wie, czym jest literatura: drogą szukania prawdy o życiu. I czym w związku z tym jest (lub nie jest) nasze pisanie o literaturze...

KP: W związku z tą skromnością, tytułami, które sugerują glosę, notatkę, zawiera się $w$ nich jeszcze jedna istotna informacja: żeby nikt nie pomyślał, że ja uzurpuję sobie prawo do tego, by napisać summę i całość - coś, co z całą pewnością orzeka. Chodziło mu zatem o to, by nie rozczarować, nie zawieść, nie oszukać czytelnika swojego tekstu. Mówił "skromnym” tytułem: proponuję pewną lekturę, ale to jest jedynie próba, bo literatura to wielka tajemnica, w stosunku do której można tylko podejmować kolejne próby czytania i rozumienia. Niech nikt nie odnosi wrażenia, że mam do przekazania „prawdę objawioną". Był bardzo skromny i świadom tego, że każdy z nas odkrywa swoje prawdy.

LI: Nie do końca zgodziłabym się z tą wielością prawd, bo Jacek był przekonany, że prawda jest jedna, choć wiele ścieżek do niej - i stąd te paradoksy w życiu Jacka.

KP: Jeśli jedna, to wielka, metafizyczna, do której nie mamy dostępu. Prawd interpretacyjnych jest wiele.

TC: Ale z drugiej strony, kiedy Jacek mówił o swoich bardzo krytycznych czy - wręcz - negatywnych recenzjach czyichś prac, to mówił w sposób bardzo zasadniczy: na przykład że ktoś się głęboko myli. Dialog owszem, ale jeśli był do czegoś przekonany, to nie godził się na rokowania.

MB-J: Myślę, że bardzo nie lubił nieuczciwości. Jeśli wyczuł w czyichś tezach rodzaj próżności czy naukowego hochsztaplerstwa, protestował. Mógł nie zgadzać się z kimś, ale gdy widział, że dana propozycja wynika z czyichś przekonań, że to jest uczciwe, nie odrzucał, nie pisał negatywnych recenzji, dawał się przekonać do zmiany stanowiska. Natomiast gry kuluarowe, wypisywanie czegoś dla mody, mnożenie słów, to go drażniło. 
TC: A jednocześnie - tak jak mówiłaś o tym własnym języku Jacka - czyjeś teksty nieliterackie czytał, zastanawiając się, jak one brzmią. Pamiętam, że kiedy redagował kilka naszych książek o poetach, wskazywał mi fragmenty, mówiąc, że źle brzmią. Uważał, że gdy ktoś czyta, to powinien mieć również estetyczną przyjemność. Nie podważał argumentacji, ale mówił: „Nie możesz tych dwóch rzeczowników umieścić obok siebie".

PD: Kiedy w doktoracie miałem wyliczenie składające się z dwóch słów, mówił: „Proszę dołożyć trzecie”. Zastanawiam się teraz, jak długo znałem Profesora - dwadzieścia lat, powiedziałbym, bliskiej relacji. Zacząłem tak jak wszyscy: od zajęć z romantyzmu. To był chyba rok, w którym zrobił habilitację. Przyszedłem na polonistykę w specyficznej sytuacji - byłem po roku z okładem filologii klasycznej. Miałem dość takiej filologii, jakiej obraz wyniosłem z zajęć na tamtym kierunku - z niezwykle mocnym dociążeniem językoznawstwa oraz niedostatkiem kształcenia historycznoliterackiego i kulturowego. Brakowało mi przede wszystkim istotnych rozmów o literaturze. Przyszedłem zatem na polonistykę i podobało mi się wszystko, począwszy od zajęć z literatury staropolskiej. Zajęcia z romantyzmu, które prowadził Profesor, były dla mnie skrajnie fascynujące - przede wszystkim ze względu na osobowość prowadzącego. Nie potrafiłem przyjść na te zajęcia nieprzygotowany. Byłem gotów przeczytać pół biblioteki, byle udowodnić Profesorowi, że zasługuję na to, by ze mną rozmawiał. Efektem tej fascynacji stała się lektura głębsza niż zwykle, lektura kontekstowa. W roku, w którym Profesor się habilitowal, zdawałem egzamin z literatury romantyzmu. Odpadło wtedy wiele osób. Zapisałem się na „zerówkę”, ale kiedy zobaczyłem, co się dzieje, postanowiłem dać sobie kolejne dwa tygodnie na lekturę. Kiedy wreszcie się odważyłem, Profesor potraktował mnie wspaniałomyślnie (był to, jak sądzę, rodzaj premii za aktywny udział w trwającym dwa semestry konwersatorium) - zadał mi pytanie jednocześnie bardzo proste i bardzo trudne: co różni Mickiewicza i Słowackiego? W domyśle: po której stronie bym się opowiedział? Nie wiem, czy szczęśliwie, ale stanąłem po stronie Mickiewicza.

MB-J: Wcale nie jestem przekonana, czy on też nie opowiedziałby się za Mickiewiczem, bo jego stosunek do tych poetów był bardzo niejednoznaczny.

PD: Później, gdy tylko mogłem, wybierałem zajęcia Profesora Brzozowskiego. Był wykładowcą, za którym szedłem przez całe studia. Naturalnie więc moja pasja na tyle rozkwitła, iż mogłem myśleć o studiach doktoranckich. To zresztą Profesor otworzył ten temat, pomógł mi się wystarać o stypendium ministerialne i prowadził wszystkie doktoratowe kwestie. Co mógłbym powiedzieć $\mathrm{z}$ rzeczy podstawowych? Jak się rozpoznaje Mistrza? Jakie było moje doświadczenie? Zawsze interesował mnie związek życia i literatury. Trafiłem na wykładowcę, który myślał podobnie: wszędzie tam, gdzie życie odrywało się od tego, co zapisane, kiedy zaczynał szeleścić papier, Profesor 
zaczynał ziewać. Od kiedy pamiętam, zawsze żywiłem przekonanie, że to jest ten podstawowy nerw literatury, punkt, w którym wszystko się zaczyna i wszystko się kończy. Podstawa relacji z Profesorem? Pokrewieństwo doświadczenia lekturowego. Profesor Jacek Brzozowski był człowiekiem, którego życie nierozerwalnie łączyło się z tym, co czytał, co komentował. W związku z tym odnosiło się wrażenie jedności. Pokazywał, że literatura i życie to jedność. Gdy musiałem porozmawiać z Profesorem o kwestiach życiowych, wytłumaczyć się z czegoś, miałem absolutną pewność, że Jego reakcja będzie konsekwencją tej najważniejszej postawy, nazwałbym ją solennym stosunkiem wobec życia i ludzi - więc także: wobec literatury, która była przezeń postrzegana jako ślad autentycznego doświadczenia egzystencjalnego. W związku $\mathrm{z}$ tym zawsze miałem pewność, że nawet $\mathrm{w}$ najtrudniejszej sytuacji Profesor wyda sprawiedliwy wyrok. Wiedziałem, że obcuję z człowiekiem starającym się mnie zrozumieć. Choć - to była konsekwencja postawy, o której próbuję opowiedzieć - Profesor nie był skłonny do wielomówstwa. Doktoranci Profesora nieczęsto słyszeli słowa pochwały. Musieli się raczej mierzyć z uwagami dotyczącymi usterek i niedoskonałości własnych tekstów. Były także mistrzowskie rady - zresztą, podane nie w formie „mistrzowskiej”, ex cathedra, lecz w zwyczajnej, serdecznej rozmowie. Tak było do końca. Przypominam sobie nasze ostatnie spotkanie, tu, w tym pomieszczeniu. Ostatnie zebranie Katedry, w którym Profesor uczestniczył. Rozmawialiśmy luźno o kwestiach warsztatowych i ktoś z doktorantów uparcie używał słowa "tekst”. Patrzyłem na Profesora. Przelotnie się do siebie uśmiechaliśmy, kiedy z uporem zastępował słowo "tekst" określeniami bardziej „ludzkimi”: wiersz, dzieło, utwór. Bo literatura jest żywą tkanką osadzoną w jakiejś tradycji mówienia i pisania o niej. Ta tkanka wymaga słów, które są adekwatne - to znaczy: nie zniekształcają, nie odrywają od życia, nie zmieniają jej w preparat. Literatura towarzyszy życiu, jest lustrem dla życia. To było dla niego fascynujące, zawsze. Gdybym nie trafił na Profesora Brzozowskiego, zapewne nie pomyślałbym o robieniu doktoratu. Był kimś, kto działał poprzez przykład, pociągnął za sobą, kto - z delikatnością i dyskrecją - dopomagał w rozwijaniu predyspozycji, które tkwiły w człowieku.

JW: On rzeczywiście potrafił szybko rozpoznawać czyjeś umiejętności i niezwykle trafnie podpowiadać pomysły, kierunki poszukiwań, tematy. Potrafił znaleźć dla kogoś pasjonujący przedmiot badań, który byłby na przykład związany z czyimiś niekoniecznie literackimi zainteresowaniami. Jacek właściwie wymyślił - w ogólnym zarysie - temat mojego doktoratu, choć przecież nie byłem jego doktorantem. Gdyby nie jego podpowiedzi, nie zająłbym się instrumentami muzycznymi i innymi muzycznymi tematyzacjami w twórczości dwudziestowiecznych poetów. Wskazał ten kierunek i był przekonany, że to dla mnie dobra droga.

LI: W Jacku była wielka troska o młodych, ale uważał, że ważna jest równowaga między egzystencją a życiem intelektualnym. Bez tego nie ma dobrej 
roboty, pracy umysłu. Pamiętam jego powiedzenie, jeszcze sprzed zmiany systemu, o profesorach, którzy zabiegali bardzo o swoje pensje: „Już sobie wszystkie skarpetki kupili!". Uważał, że powinni młodym zabezpieczyć byt, bo to wtedy dokonuje się odkryć. Dla mnie to był przejaw bezinteresowności Jacka. Wspinał się po uniwersyteckich szczeblach, ale widział potrzeby młodych, tych aspirujących.

PD: Nie tylko te finansowe. Profesor przez długie lata współpracował z Asią Sikorzanką ${ }^{14}$ i Radiem Łódź - bez żadnych profitów, a to była czasem absorbująca praca. Pamiętam, jeszcze kiedy studiowałem, Asia zorganizowała wyjazd kilku młodych piszących osób do Borek nad Zalewem Sulejowskim. Profesor pojechał z nami jako mistrz warsztatu. I tam, w Borkach, różne rzeczy - mądre i niemądre - pisaliśmy, komentowaliśmy. Dla mnie, zafascynowanego Profesorem, to był kapitalny wyjazd. Zobaczyłem Go w oderwaniu od rzeczywistości uniwersyteckiej.

MB-J: Myślę, że sednem jego literaturoznawczej pasji było właśnie spotkanie z człowiekiem, nie $\mathrm{z}$ tekstem, $\mathrm{z}$ tego też wynikała jego niechęć do rozmaitych metodologii. On się nimi właściwie nie posługiwał. Nie lekceważył - znał, orientował się, ale to go nie interesowało.

KP: Jacek był cały czas hermeneutą. To była dla niego postawa najważniejsza.

LI: Nie etykietował.

MB-J: Zdecydowanie nie. Wykorzystywał narzędzie, które uznał w danej chwili za pomocne, ale generalnie to było nieistotne.

TC: A czy znaleźlibyście takich autorów, których Jacek w swoim pisaniu przewartościował, odczytał dla siebie na nowo? Do Różewicza wracał bardzo konsekwentnie.

MB-J: Wracał też do Szymborskiej.

KP: Z Szymborską to nie była taka prosta sprawa... Ja chyba najpóźniej $\mathrm{z}$ was poznałam Jacka, bo nie pracowałam tutaj, robiłam doktorat w IBL-u. Zetknęłam się z Jackiem na zorganizowanej w Łodzi sesji Diabeł w literaturze polskiej wiosną 1994 roku - mogłabym powiedzieć, że diabeł nas połączył. Słyszałam wcześniej o Jacku, że to świetna osoba, pełen pasji naukowiec,

${ }^{14}$ Joanna Sikorzanka, redaktor Radia Łódź, absolwentka filologii polskiej UŁ i dziennikarstwa UW. Współpracowała przez wiele lat (od roku 1993) z Jackiem Brzozowskim, prowadząc z nim cykl audycji Do piór (z poradami i ocenami dotyczącymi wierszy pisanych przez słuchaczy) oraz organizując radiowe konkursy poetyckie (nagrodzone utwory były publikowane w tomikach Serii Poetyckiej Radia Łódź). Była też redaktorem jego cyklicznych audycji literackich poświęconych późnej twórczości poetów, Mickiewiczowi, Słowackiemu, oraz arcydziełom poezji polskiej. 
ale bardzo ostry w sądach. Przyjechałam z referatem na temat Wata, którym się wówczas zajmowałam, i słuchałam wystąpienia Jacka - mówił o duchu z prologu trzeciej części Dziadów. To było dla mnie fascynujące, porywające - dlatego że odkryłam, jak mocno ten duch wiąże się z moim życiem. Nigdy o tym tak wcześniej nie myślałam. A potem przeżyłam niesamowity moment, kiedy po swoim wystąpieniu dostałam od Jacka kartkę - a myśmy się przecież nie znali. Napisał mi - mogę się pochwalić - "To było znakomite”. Ta opinia niezwykle dowartościowała dla mnie samej moją pracę. Wtedy też narodziła się między nami szczególna więź, staliśmy się sobie bliscy, zaczęliśmy się przyjaźnić, godzinami rozmawialiśmy przez telefon o literaturze. To było niesamowite i stanowiło dowód, że literatura może ludzi ze sobą łączyć. Zaczęliśmy czytać teksty dla siebie ważne. Kiedyś zaproponowałam, żeby kolejną sesję poświęcić Szymborskiej, mojej ukochanej poetce, a Jacek zapytał: „Myślisz, że tam coś jest?”. Co pokazuje, jak był otwarty, bo na początku to na pewno nie była jego poetka. Chciał ją jednak przeczytać, poznać, spróbować dla siebie odkryć. I okazało się, że z biegiem czasu stawała się coraz bardziej jego...

MB-J: I odkrył w niej całkiem sporo. Jacek wracał też do wielu książek z literatury powszechnej, które czytywał w różnych momentach swojego życia, rzeczywiście przemyśliwał, zmieniał o nich sądy. Myślę o Conradzie, o Czarodziejskiej górze - lekturze życia.

KP: To na pewno była dla niego najważniejsza powieść. Pamiętam, kiedy - czytając kolejne nowości, i z ciekawości, i z obowiązku - mówiłam: "Jacek, niezłe to jest”. A on: „Wiesz co, po Czarodziejskiej górze...”. Chciałabym powiedzieć o ostatnim tekście z literatury powszechnej, o którym mówił, że chciałby coś o nim napisać - to był Wyrok Kafki. Dopiero po rozmowie z nim zdałam sobie sprawę, jak ten utwór jest niepochwytny. Nigdy nie zadałam Jackowi pytania o to, dlaczego Wyrok był dla niego taki ważny. Najkrócej mówiąc, to opowiadanie o tym, że zawsze jest zasadniczo inaczej, niż się początkowo wydaje.

MB-J: Mam wrażenie, że to opisuje trochę Jacka. To znaczy, Jacek wygłaszał otwarcie pewne poglądy, czasem bardzo ostre, ale jednocześnie wiedział (i my to czuliśmy), że jest pewna granica, poza którą on jako człowiek, jako mężczyzna, nikogo nie wpuści. Jego sfera najczulsza, najgłębsza, w której stawiał sobie jakieś najważniejsze, fundamentalne pytania. Zawsze miałam wrażenie, że istniała $\mathrm{w}$ nim taka samotna przestrzeń tajemnicy, do której nikogo nie mógł dopuścić, bo to była część jego tożsamości.

LI: Zresztą także w najbardziej ludzkim wymiarze. Mam garść anegdot, z różnych okresów znajomości z Jackiem. Naprowadzasz mnie na jedną z nich: wyjazd ze studentami w roku 1988, wspólny. Poprosiłam Jacka, żeby dołączył do nas jako opiekun grupy. Postawił dwa warunki: pierwszy, że 
jedzie z nim Konrad; drugi taki, że będzie miał osobny pokój, ponieważ chrapał i nie zamierzał się tego wstydzić, mieszkając z innymi. Zorganizowaliśmy więc wszystko w Szczyrku tak, żeby miał zapewnioną intymność, osobność. Wieczorami, w wynajętej dla nas willi, tańczyliśmy. Pamiętam, Jacek był wtedy skonfundowany. Mówił: „Wiesz, tak ruszać nogami, to jest jakieś nienormalne". Siedział przy radioodbiorniku, wciskał klawisze. Mówię: „Będziesz naszym diskdżokejem”. „Jeśli znajdziemy coś do słuchania”. I tańczyliśmy do muzyki barokowej, to było naprawdę niezwykłe. Jeszcze wieczorem, po tych tańcach, poszliśmy na spacer, siedzieliśmy na huśtawkach na jakimś placu zabaw i rozmawialiśmy o Grze szklanych paciorków. Skrępowanie własnym ciałem - to pamiętam u Jacka. On patrzył na taniec innych, patrzył z podziwem na dziewczyny, które tam pląsały, ale wydawało mu się niedorzeczne to, że on sam miałby się tak zaangażować. A druga rzecz, która przychodzi mi na myśl w związku z tym wyjazdem, to - mówię z całą odpowiedzialnością - najwspanialszy wykład, jaki w życiu usłyszałam. Ponieważ budziłam się wcześnie rano, integrowałam młodzież przy wspólnym stole śniadaniowym. Robiłam kanapki, wiecie, 1988 rok - pasztet, nic specjalnego. Ale postanowiłyśmy z jedną ze studentek, że te kanapki będą urozmaicone i na wykałaczki nadziewałyśmy zielony groszek. Była godzina dziesiąta, Jacek do nas dołączył. Ta dziewczyna - Beata - patrzy na niego ogromnymi oczyma i mówi: „Muszę przyznać, że Dziady to wyjątkowo nieciekawa lektura". Jackowi niewiele było trzeba. To był wykład trwający dwie i pół godziny, nikt nie odchodził od stołu.

KP: Musiał się wściec...

LI: Nie było widać po nim wściekłości, widać było chęć przekonania, że w tym tekście jest jednak coś, czego ona nie dostrzega. To jak z tą ironią, o której mówił Tomek - żeby przekonać rozmówcę, że jest głuchy i ślepy na pewne rzeczy, które warto odkryć. Absolutnie najlepszy wykład, jaki słyszałam w życiu! W takich warunkach siedzieliśmy nad tym pasztetem, zapominając, że to śniadanie...

JW: Dodałbym jeszcze parę słów w związku z jego przewartościowaniami ocen dorobku pisarzy. Pamiętam, że Jacek był zawsze wielkim wyznawcą Mickiewicza. Odnosiło się nawet wrażenie, że będzie trwać tylko przy nim. Z czasu, kiedy pisał swoją książkę habilitacyjną - pewnie około 1988 roku - zapamiętałem takie dwie sytuacje. Zdarzało się, że jako młody nauczyciel, pod koniec lat osiemdziesiątych, odwiedzałem Krysię Ratajską, najczęściej po to, żeby się zwierzać z różnych swoich szkolnych niepowodzeń. I parokrotnie spotkałem tam Jacka, który przychodził do niej, by rozmawiać nie tylko o literaturze, ale na przykład o wychowaniu dzieci (bo przecież jego syn Konrad i córka Krysi to niemal rówieśnicy). Kiedyś Jacek musiał wcześniej wyjść, ja zostałem dłużej, i Krysia powiedziała: „Wiesz, to jest człowiek, co do którego jestem pewna, że napisze zupełnie nową i świetną książkę 
o Mickiewiczu". Wkrótce przekonałem się, jak Jacek mówi o Mickiewiczu, jak o nim pisze. I z jego różnych seminaryjnych wystąpień zapamiętałem taką wypowiedź, kiedy nagle pojawiło się nazwisko Słowackiego i Jacek z wielką dezaprobatą mówi: „E tam, taki bluszczowaty poeta”. Na co Romek Kanarek ${ }^{15}$ i Ninka Zielakowa protestują. Minęło kilka lat i okazało się, że Jacek jest wydawcą Słowackiego...

TC: W pewnym momencie wszystko kojarzyło mu się ze Słowackim...

JW: Tak, i tutaj warto nawiązać do opublikowanego w Internecie filmiku o Jacku, przygotowanego przez studencką telewizję. Tam pada pytanie: "Dlaczego akurat Słowacki?". A Jacek odpowiada: „Bo ja go nie rozumiem”. I to jest ta zasadnicza motywacja gruntownych studiów nad Słowackim!

TC: Bo Jacek szukał i znalazł u Słowackiego prawdę jego życia. Pamiętacie, z jakim przejęciem pokazywał notatki z plamami krwi?

MB-J: Wydaje mi się, że w ogóle Jacka ciekawiły nieoczywistości, rzeczy nierozstrzygnięte. Im bardziej były dla niego niejasne, tym bardziej wymagały zaangażowania. Myślę, że on by jeszcze wrócił do Mickiewicza, napisał tę planowaną od dawna książkę o milczeniu. Zastanawiał się nad nią już w czasie pracy nad habilitacją. Pisał wtedy o poecie, ale stale pamiętał, że jest jeszcze nie-poeta - ten, który milczy.

BS: Mickiewicz i Słowacki - dwie jego wielkie fascynacje. Ale też Jacek kilkakrotnie mówił, że Mickiewicz zachował się skandalicznie wobec Słowackiego.

JW: Bo jeśli chodzi o formułowanie ocen, był człowiekiem głęboko sprawiedliwym. Tak, jak w przypadku tej opinii o Mickiewiczu. To nie było podporządkowane jakiejkolwiek strategii - po prostu, jeśli coś jest nie tak, trzeba o tym powiedzieć. Te jego oceny - przecież niejednokrotnie bardzo surowe - były jednak zawsze podyktowane życzliwością. Co więcej - dobrem ocenianego, którego trzeba po prostu jak najszybciej zawrócić ze źle obranej drogi. Był uwrażliwiony na nadużycia myślowe. Poza tym denerwowało go zakłamanie i pozerstwo. Nie znosił głupoty.

TC: I dlatego głęboko przeżywał wydarzenia polityczne, dawniej i w ostatnich latach. $\mathrm{W}$ jego teczce personalnej, którą przeglądałem, przygotowując nekrolog, znalazłem informację, że dziekan Wydziału Filologicznego udzieliła mu indywidualnego upomnienia „w związku z zachowaniem się dnia 10.11.1982 na przerwie 12-12.15 w gmachu Wydziału". Sprawa miałaby

\footnotetext{
${ }^{15}$ Dr Romuald Kanarek (1946-2016), pracownik łódzkiej polonistyki od roku 1970. Od 1981 roku w zespole Katedry Literatury Romantyzmu i Literatury Współczesnej UŁ - na stanowisku adiunkta; od roku 2003 - starszy wykładowca w Katedrze Literatury i Tradycji Romantyzmu UŁ. W 2011 roku przeszedł na emeryturę.
} 
może ciąg dalszy, ale rektor nie widział potrzeby wszczęcia postępowania dyscyplinarnego (czego ślad też jest $\mathrm{w}$ dokumentach). O co chodziło? Jacek wsparł jakąś manifestację studentów w przeddzień nieuznawanego przez władze PRL Święta Niepodległości (11 listopada). Nigdy o tym nie wspominał, bo najważniejsza w rozmowach była dla niego jednak literatura. Zachowania polityczne uważał za oczywistość, o której nie było potrzeby mówić. Zapytałem go kiedyś od niechcenia, podczas kijowskiego Majdanu, czy weźmie udział w manifestacji na Piotrkowskiej wspierającej Ukraińców. Po prostu przyszedł.

BS: W pewnym okresie swego uniwersyteckiego życia Jacek często chodził do pokoju Jurka Poradeckiego, gdzie rezydowali też Błażejewski ${ }^{16}$ i Rzymowski ${ }^{17}$. I robił to $\mathrm{z}$ wielkiej potrzeby uczestniczenia $\mathrm{w}$ rozmowach o literaturze. Jako młody adept nauki zaglądał tam bardzo często, ciągle miał taką potrzebę. A w czasie konferencji na Rogach ${ }^{18}$, w przerwach obrad, wędrował na spacery z Ewą Ledóchowicz ${ }^{19}$. To ona była wówczas partnerką do rozmów o literaturze. Chcę podkreślić, że miał wciąż potrzebę szukania rozmówców o literaturze. Aż przyszedł w jego badaniach taki etap, kiedy zajął się edytorstwem. To mniej więcej ten czas, gdy zaczął poświęcać się pracy nad Słowackim. W Stowniku literatury XIX wieku jest jego hasło o poemacie dygresyjnym, w którym oczywiście wiele pisze o Słowackim. To bardzo dobry tekst. Wydaje się, że z analitycznego charakteru postawy badawczej Jacka wyniknęła też jego późniejsza pasja edytorska; pod koniec życia najbardziej lubił właśnie to - krytyczne prace edytorskie. Mówił wtedy, że nie powinien już pisać artykułów interpretacyjnych. Nawet kiedy opracowywał

${ }^{16}$ Prof. dr hab. Tadeusz Błażejewski (ur. 1944), historyk literatury polskiej, pracownik UŁ od roku 1967. Kierownik Katedry Literatury Romantyzmu, Dwudziestolecia Międzywojennego i Literatury Współczesnej UŁ w latach 2003-2007, a w latach 2007-2008 kierownik Katedry Literatury XX i XXI wieku UŁ. Jego zainteresowania badawcze wiązały się najściślej $\mathrm{z}$ problematyką przemian form artystycznych $\mathrm{w}$ prozie dwudziestowiecznej. Opublikował m.in. książki: Retorta Fausta (Łódź 1982), Literatura jak literatura (1988), Przemoc świata. Pisarstwo Leopolda Buczkowskiego (1991), a także słowniki biobibliograficzne Łódzkie środowisko literackie (1981) oraz Wspótczesna Łódź literacka (1989). Ze względu na stan zdrowia przeszedł na wcześniejszą emeryturę w 2008 roku.

${ }^{17}$ Dr Jerzy Rzymowski - nauczyciel akademicki od 1968 roku, p.o. prodziekana Wydziału Filologicznego Uniwersytetu Łódzkiego (1993-1996). W pracach naukowych i krytycznoliterackich (m.in. w „Miesięczniku Literackim”, „Nowym Wyrazie”, „Osnowie”, „Odgłosach") zajmował się głównie twórczością XX wieku oraz historią powieści. Rozprawę doktorską Andrzej Strug w kręu literatury i polityki napisał pod kierunkiem prof. dra Zdzisława Skwarczyńskiego (1977). Opublikował m.in. Erynie historii i człowieka. O pisarstwie Leona Gomolickiego (1973) oraz opracował wstęp, posłowie i komentarze do dwutomowej edycji Pism wybranych Andrzeja Struga (1987). W 2012 roku przeszedł na emeryturę.

${ }^{18}$ Rogi to nazwa osiedla położonego na obrzeżach Lasu Łagiewnickiego w północnowschodniej części dzisiejszej Łodzi, gdzie znajduje się jeden z domów konferencyjnych Uniwersytetu Łódzkiego.

${ }^{19}$ Ewa Ledóchowicz (ur. 1959), absolwentka polonistyki UŁ i historii sztuki UW; od ponad dwudziestu lat środkowoeuropejski przedstawiciel amerykańskich wydawnictw naukowych (Harvard University Press, Yale University Press, University of Chicago Press); tłumacz literatury pięknej z języka angielskiego na język polski. 
redakcyjnie nasze pokonferencyjne tomy zbiorowe, robił to z radością dziecka - po nocach, błyskawicznie. Zdarzało się, że dzwonił do mnie z powodów językowych, na przykład kiedy trafił w tekście na jakiś passus po francusku. Jakiż on był dociekliwy! Chciał znać wszystkie niuanse znaczeniowe.

MB-J: Kiedy zaczęła się ta edytorska przygoda? Po habilitacji?

KP: Zaczęła się w roku 1999, bo wtedy była sto pięćdziesiąta rocznica śmierci Słowackiego. Jacek został powołany do komitetu honorowego. Przymierzano się do innej edycji, która nie doszła do skutku. Jacek ciągle powtarzał, że nie rozumie Słowackiego. Mickiewicz był mu jakoś bliski, Słowacki - obcy. Pamiętam, jak po wielu latach takich interpretacyjnych rozmów z Jackiem o literaturze zapytałam, czy mu nie brakuje intensywnych interpretacji tekstów? Odpowiedział, że de facto każda decyzja edytorska jest interpretacją. Mam wrażenie, że im bardziej się zagłębiał w rękopisy, tym bardziej sobie uświadamiał, że nie istnieje coś takiego jak ostateczna wersja tekstu. I miał poczucie, że jeśli interpretacja jest możliwa, to tylko poprzez edytorstwo. Powiedział mi: „Ja nie porzuciłem interpretacji, ja zmieniłem sposób jej uprawiania".

PD: Czytanie w procesie. Dla nas to jest oczywiste - Jego książki. Zwróćcie uwagę na motta, przypisy, parateksty. Oglądam książki Profesora na przykład pod kątem słowa wstępnego i zamykającego. Jakie to ciekawe rzeczy! Czasem nie ma żadnego wprowadzenia - jak w Odczytywaniu romantyków. W Odczytywaniu romantyków (2) napisał tak: „Gdyby przyszło mi wytłumaczyć tę książkę, miałbym kłopot. [...] Owszem, mógłbym napisać, że wybrałem do niej dwadzieścia dwa teksty - szkice, notatki, okruchy interpretacyjne - pisane na przestrzeni ostatniej dekady [...]. Mógłbym też stwierdzić, że tak właśnie zwykło się robić: zbierać prace rozproszone, by się nimi w jednym miejscu podzielić. Mógłbym na koniec dodać, że wybrałem te, a nie inne teksty, ponieważ są dla mnie ważne - ważne prywatnie, jestem do nich z takich czy innych powodów przywiązany. [...] Nie umiem powiedzieć, dlaczego zajmują mnie drobiazgi - było nie było u wielkich, i tylko u nich: Mickiewicza, Słowackiego, Norwida. I nie umiem powiedzieć, dlaczego o tych drobiazgach piszę na ład hipotez. Jedyne, co umiem, to wyznać - ryzykując posądzenie o afektowaną skromność - że inaczej pisać nie umiem i że zajmować się nie-drobiazgami również ani nie umiem, ani nie chcę. I może jeszcze tyle zaryzykuję, że dopowiem, iż gdyby wolno mi było metaforycznie określić, jak widzę to swoje «odczytywanie romantyków», dałbym jako motto do książki następujący wyimek". Teraz następuje cytat z Prozodii polskiej Józefa Franciszka Królikowskiego, nadzwyczajny, kapitalnie dobrany, służący tu jako błyskotliwy autokomentarz: „Nie byłoby rzeczą niegodną badacza udać się umyślnie do kuźni kowalskiej natenczas, kiedy około większej sztuki żelaza pracują. Majster albo starszy czeladnik, który na kowadle obraca żelazo, trzyma zwykle mały młotek. Nie zawsze nim bije 
w obrabiające się żelazo, ale za to uderza w kowadło. Może się z tego nie zawsze wytłumaczyć, wie to jednak dokładnie, że gdyby tego uderzenia w kowadło zaniechał, drudzy pracownicy młotami bałamucić zaczną; wie i to dokładnie, że przy tak porządnym biciu praca ich staje się mniej uciążliwą". Profesor Jacek Brzozowski - majster, mistrz naszego rzemiosła - daje tu manifest filologicznej skromności. My - interpretatorzy, hermeneuci, historycy literatury - jesteśmy tylko sługami tego, co większe od nas, tajemnicze i niepojęte. Dopisujemy coś na marginesach wielkich dzieł przeszłości, wciąż na nowo musimy sobie uświadamiać wtórny, służebny charakter owej pracy. Większość badaczy literatury o tym nie pamięta, nie chce pamiętać. Profesor wiedział to od samego początku. Świadczy o tym, między innymi, przytoczony wyżej - kompletnie nienaukowy! - wstęp do Jego książki. Ta cecha Jego świadomości nieodmiennie mnie fascynowała.

TC: Ale to jest swoiste credo badawcze.

PD: Jesteśmy przyzwyczajeni do wstępów, w których objaśnia się koncepcję, przedstawia metodologię.

MB-J: Nie wszystkich byłoby stać na to, żeby taki wstęp napisać.

PD: Kolejny przykład - Postscriptum: Usprawiedliwienie do książki o późnych wierszach poetów. Jedna stroniczka na temat Jarosława Iwaszkiewicza i jego wiersza Urania. Ten utwór jest przytoczony, po czym następuje akapicik: „Powiedziano o tym wierszu niemało. Owszem, w zwięzłym komentarzu jakieś drobiazgi można by do tego dorzucić. Rzeczy zasadnicze przecież - wypadłoby powtórzyć za poprzednikami. To jedyny powód, dla którego szkic o Uranii nie znalazł się w tej książce. Nie sposób jednak było tego wiersza, jednego «z piękniejszych, jakie napisano w Polsce po wojnie», nie przypomnieć". Nie napisał o tym wierszu, ale napisał.

KP: Jakby chciał pokazać, że nie trzeba na siłę napisać. Czasem uczciwiej nie napisać. Warto pisać jedynie rzeczy konieczne.

PD: Ale paradoksalnie u Profesora konieczne były właśnie „boki”, glossy, dopiski na marginesach. Choć przecież pisał też rzeczy absolutnie fundamentalne, wchodzące $\mathrm{w}$ samo centrum literatury romantyzmu i literatury w ogóle. Myślę, na przykład, o tekstach na temat wierszy lozańskich Mickiewicza, na temat Czarodziejskiej góry Miłosza.

LI: Przypomina mi się wizyta w Muzeum Fałata i Jacek, który zatrzymuje się przed dwoma japońskimi obrazkami, które Fałat sobie przywiózł. Czyli nie zajmuje go sam Fałat, tylko powód, dla którego zainteresował się sztuką japońską. Można było się tym w ogóle nie interesować, a on zatrzymał się właśnie przy tym i do tego wracał. 
PD: Uparcie powracał do opowieści o kupie śmieci, którą Mickiewicz oglądał przed grotą Homera w Smyrnie...

MB-J: To jest kwestia proporcji. Kiedyś napisał mi taką dedykację: „Kilka drobiazgów o niedrobnej poezji".

JW: Ale z drugiej strony Jacek napisał monografię o Panu Cogito. I to już nie jest drobiazg.

KP: Mam przed sobą jeden z jego kanonicznych tekstów. Kiedy poznałam Jacka i ta relacja się zacieśniała, pomyślałam sobie, że to jest niesamowite, bo czytam tę książeczkę, jakby Jacek nie pisał o Panu Cogito, tylko o sobie. W sposób zatajony przedstawia swój sposób myślenia. Napisał o świecie wartości i wyborów Pana Cogito, w istocie zaś o tym, co dla niego jest najważniejsze.

TC: Dopowiedzmy więc jeszcze jedną rzecz: późne literaturoznawcze teksty Jacka to nie były teksty stricte literaturoznawcze. To była praca żałoby po śmierci Ewy, żony. Przyzwyczaił nas do tego, że jeśli coś proponował, to dotyczyło to śmierci albo choroby, utrzymane było zawsze $\mathrm{w}$ tym samym duchu. To świadectwo tego, jak Jacek literaturę i literaturoznawcze pisanie traktował.

KP: Jest taki późny wiersz Szymborskiej, który mi teraz często przychodzi do głowy, i mam wrażenie, że on jest w jakiś sposób o Jacku, bo on by zapewne podobnie odpowiedział na zadane $\mathrm{w}$ utworze pytania:

Spytałam go o tamte czasy,

kiedy byliśmy jeszcze tacy młodzi,

naiwni, zapalczywi, głupi, niegotowi.

Trochę z tego zostało, z wyjątkiem młodości

- odpowiedział.

[...]

Spytałam go o zdjęcie,

to $\mathrm{w}$ ramkach, na biurku.

Byli, minęli. Brat, kuzyn, bratowa,

żona, córeczka na kolanach żony,

kot na rękach córeczki,

i kwitnąca czereśnia, a nad tą czereśnią

niezidentyfikowany ptaszek latający

- odpowiedział.

Spytałam go, czy bywa czasami szczęśliwy.

Pracuję

- odpowiedział. 



\section{Jacek}

\section{Brzozowski}

W swojej działalności zawodowej, od momentu zatwierdzenia habilitacji do osiągnięcia statusu emeryta, wypromowałem dwudziestu sześciu doktorów, ośmioro $\mathrm{z}$ nich cieszy się obecnie tytułem naukowym profesora, a jedna z pań jest członkiem korespondentem Polskiej Akademii Nauk. Zaczynało pod moją opieką pracę osób więcej, nie wspominam o tych, którzy nie osiągnęli stopnia doktora. Przerywano wysiłki z różnych powodów, takich czy innych powikłań życiowych, utraty wiary we własne zdolności itp. Nie tu miejsce, by się zastanawiać nad przyczynami takiego toku rzeczy. Wspomnę tylko, że większość doktorantów rekrutowała się spośród pracowników bądź stypendystów Instytutu Badań Literackich, ale bynajmniej nie wszyscy. Byli wśród nich także absolwenci znakomitej Szkoły Nauk Społecznych, założonej w roku 1993 przez Stefana Amsterdamskiego przy Instytucie Filozofii i Socjologii PAN, a także osoby, które po prostu ze mną się skontaktowały i spytały, czy nie byłbym gotów podjąć się obowiązków promotora. $\mathrm{W}$ takiej sytuacji umawiałem się $\mathrm{z}$ kandydatem na mojego podopiecznego na rozmowę i zależnie od jej przebiegu podejmowałem decyzję. Gdy zorientowałem się, że istnieje szansa, iż taka współpraca może dać pozytywne wyniki, funkcji promotora zazwyczaj się podejmowałem.

Początki mojej współpracy z profesorem Jackiem Brzozowskim kształtowały się nieco inaczej. Do Instytutu Badań Literackich przybywali stażyści, a byli nimi nie tylko zagraniczni poloniści, także młodzi pracownicy (bądź doktoranci) rodzimych uniwersytetów. Zazwyczaj staże te trwały krótko, rzadko przekraczały wymiar trzech miesięcy. Przypadek Jacka Brzozowskiego był inny. O ile wiem, zgodnie z przyjętą normą został skierowany przez macierzysty Uniwersytet Łódzki, ale na dłużej, niż to się zwykle działo, to u nas właśnie miał pracować nad doktoratem i doprowadzić go do pozytywnego końca. Nie jestem świadom, jak to się stało, że promotor miał wywodzić się z IBL-u, zazwyczaj bowiem funkcję tę obejmował samodzielny (tak to się wtedy oficjalnie nazywało), czyli habilitowany, wykładowca 
pracujący na uczelni, z której wywodziła się dana osoba. W Instytucie Jacek został skierowany do Pracowni Poetyki Historycznej, z którą byłem związany od początków jej istnienia - i mnie przypadła funkcja promotora (dotyczyło to także drugiej osoby z Uniwersytetu Łódzkiego, mającej podobny do Jacka status, ona wszakże z pracy naukowej zrezygnowała). W tym miejscu chciałbym sprostować pewną nieodpowiadającą rzeczywistości informację, która znalazła się $\mathrm{w}$ haśle jemu poświęconym $\mathrm{w}$ tomie trzecim słownika biobibliograficznego Polscy pisarze i badacze literatury przetomu XX i XXI wieku (2016); autorką tego biogramu jest Barbara Marzęcka. Otóż Janusz Sławiński nie był nigdy promotorem rozprawy doktorskiej Jacka Brzozowskiego, tę funkcję wraz z jego przyjściem do Instytutu powierzono mnie. Ta fałszywa wiadomość stąd prawdopodobnie się wzięła, że wówczas profesor Sławiński był szefem tej Pracowni, a wkrótce w ramach reorganizacji Instytutu awansował i został kierownikiem całego pionu teoretycznoliterackiego. Bycie szefem danego zespołu nie równa się jednak byciu promotorem każdego, kto przygotowuje $\mathrm{w}$ danym zespole rozprawę doktorską.

Nasze relacje od początku układały się bardzo dobrze. Istnieją po temu zwykle odpowiednie warunki, gdy doktorant proponuje osobie, która ma się stać jego opiekunem, temat rozprawy, choćby w najogólniejszych zarysach. Samą inicjatywę należy oceniać jako cenną. Jacek już w czasie początkowych kontaktów (przedtem się nie znaliśmy) zaproponował temat swojego dzieła doktorskiego, temat, który od razu mi się spodobał, interesowały mnie bowiem historie poszczególnych topoi, a historia wątku muz w poezji polskiej wydała mi się istotna i warta podjęcia także z tego względu, że pozwalała łączyć podejście właściwe historii literatury z ujęciem charakterystycznym dla poetyki, inwokacje do muzy to nie tylko motyw, to także element pewnych osadzonych w literaturze gatunków. Nie jestem tego pewien, moja pamięć w tym przedmiocie może być zawodna, ale wydaje mi się, że pierwotnie była mowa o dziejach toposu muz w wymiarze całej polskiej poezji - od początków po współczesność. Dopiero po jakimś czasie zorientowaliśmy się, że takie założenie jest zbyt maksymalistyczne, co spowodowałoby znaczne przedłużenie czasu pracy nad rozprawą i - co za tym idzie - przesunęłoby obronę pracy doktorskiej, zwieńczonej otrzymaniem stopnia doktora, w bliżej nieokreśloną przyszłość. Na taką rozrzutność nie można było sobie pozwolić, choćby ze względu na obowiązujące przepisy. Toteż postanowiliśmy, że na użytek doktoratu teren obserwacji kończyć się będzie na przełomie romantycznym. Przypuszczałem, że dalsze losy wątku muz w poezji polskiej zostaną omówione $\mathrm{w}$ tomie drugim, który będzie rozprawą habilitacyjną. Stało się inaczej, nie wiem, z jakich powodów Jacek zrezygnował z kontynuacji. Może temat mu się znudził, a może uznał, że muzy od pierwszych dekad XIX wieku zeszły na margines twórczości poetyckiej i trudno im będzie poświęcić książkę, która byłaby podstawą zabiegów o przyznanie stopnia doktora habilitowanego.

Chciałbym podkreślić kilka rzeczy. Muzy w poezji polskiej. Dzieje toposu do przetomu romantycznego to książka nader bogata pod względem erudycyjnym. 
Badacz podejmujący taką problematykę musi bowiem być znawcą tego, co stanowi bezpośredni temat, to jest oczywiste, ale musi się także doskonale orientować w sięgających głębokiej starożytności jego dziejach, bo sprawą o znaczeniu podstawowym staje się kwestia tradycji. Kiedy się jej nie uwzględnia, nie sposób w ogóle o tych sprawach mówić. W książce tego typu erudycja ogarniać musi nie tylko zresztą antyczny spadek, wymaga również znajomości poetów staropolskich - nie tylko wybitnych, ale także tych, którzy wielkości nie osiągnęli i zostali w wielu wypadkach zapomniani. Inny walor pracy, godny wydobycia: jest to książka świetnie napisana. Mogę się o tym wypowiadać nie tylko jako promotor, ale także jako w pewnym sensie jej wydawca. Ukazała się ona bowiem w serii „Rozprawy Literackie”, firmowanej przez Komitet Nauk o Literaturze Polskiej, a ja przez długie lata byłem przewodniczącym Komitetu Redakcyjnego (zwano ją przez długi czas „serią z piórkiem” ze względu na motyw gęsiego pióra na okładce). W jakiejś mierze była to seria debiutów, a w każdym razie autorów młodych, znajdujących się u początków drogi. Opublikowany w niej debiut książkowy Jacka Brzozowskiego należy do najlepszych, jakie w niej się ukazały. Chciałbym zwrócić uwagę na pewien paradoks: jest regułą, że im lepsza praca doktorska, im doktorant jest intelektualnie bardziej samodzielny, tym promotor ma mniej pracy, ale też tym więcej chwały również na niego spływa. Omawiany przypadek paradoks ów potwierdza. W sukcesie tej rozprawy moja rola była niewielka. Kiedy podejmowałem się tej funkcji, Jacek Brzozowski był już jak na swój wiek doświadczonym historykiem literatury, świadomym poznawczych celów, do których osiągnięcia zmierza.

Z samej obrony niewiele zostało mi wspomnień. Odbyła się ona na Uniwersytecie Łódzkim. O ile pamiętam - ze sporym opóźnieniem w stosunku do wyznaczonej pierwotnie godziny. Poprzedzało ją posiedzenie Rady Wydziału, które się przeciągnęło poza planowany czas. Czekaliśmy cierpliwie. Utrwalił się w mojej pamięci doktorski obiad - przede wszystkim ze względu na miejsce, w jakim się odbył, albowiem zaprosił nas Jacek do Grand Hotelu, w ten sposób - mimo że w Łodzi zdarzało mi się bywać - znalazłem się po raz pierwszy w tym historycznym budynku. Zapamiętałem rozległą salę restauracyjną, utrzymaną $\mathrm{w}$ uroczystym stylu sprzed lat kilkudziesięciu.

Po zakończeniu procedur doktorskich nasze kontakty normalną koleją rzeczy się rozluźniły. Spotykaliśmy się od przypadku do przypadku, choć z daleka obserwowałem jego działalność naukową. Dostrzegłem, że zajmował się przede wszystkim, jeśli nie wyłącznie, poezją - jako interpretator, inspirator tomów zbiorowych i - przede wszystkim - naukowy edytor. Myślę tu zwłaszcza o monumentalnym tomie Wierszy Słowackiego, wydanym w roku 2005, przygotowanym wspólnie z profesorem Zbigniewem Przychodniakiem z Uniwersytetu Adama Mickiewicza w Poznaniu i opatrzonym podtytułem Nowe wydanie krytyczne. Jacek ujawnił tu świeże ukierunkowanie swoich naukowych zainteresowan. Okazał się - podobnie jak współwydawca - wytrawnym filologiem. Nie ulega wątpliwości, że każdy kolejny specjalista podejmujący trud wydawania dzieł wielkiego poety będzie musiał brać 
pod uwage propozycje tekstologiczne zawarte $\mathrm{w}$ tej edycji. Trudno mi się odnosić do tych spraw, jestem bowiem w tej materii wysoce niekompetentny, nigdy edytorstwem naukowym się nie zajmowałem. Mogę jednak powiadomić, że wysoko cenię pracę obydwu wydawców, która doprowadziła do powstania omawianej edycji krytycznej, zapewne pierwszej tak rozległej po dokonaniach Juliusza Kleinera i jego współpracowników w tej dziedzinie.

Niepokojąca wiadomość o ciężkiej chorobie Jacka dotarła do mnie dość dawno. Po raz ostatni widziałem go w połowie grudnia roku 2016. Dokładnie pamiętam tę datę, a także miejsce i sytuację, działo się to bowiem w Teatrze Nowym w czasie uroczystości, podczas której wręczono mi łódzką Nagrodę Literacką im. Tuwima. Chwilę rozmawialiśmy, Jacek wyglądał marnie, nie trzeba było wielkiej dociekliwości, by stwierdzić, że nie jest zdrowy. Chyba nie miałem złudzeń, nie sądziłem jednak, że smutna wieść o jego śmierci nadejdzie w niedalekim czasie, zaledwie nieznacznie później po tym ostatnim spotkaniu. Na tym zakończę moją opowieść o Jacku Brzozowskim. 


\section{Wspomnienie \\ o Jacku pół roku po Jego śmierci}

Profesor Jacek Brzozowski, uczony, nie całkiem odszedł - żyje w pozostawionych książkach i artykułach; za ich pośrednictwem jego głos będzie uczestniczyć w niejednej naukowej, badawczej dyspucie. Lecz człowiek - odszedł.

Poznaliśmy się z Jackiem w latach osiemdziesiątych. Najpierw ja byłam studentką polonistyki, on - asystentem. Prowadził zajęcia z komparatystyki literackiej. Czytaliśmy utwory bardzo różne, od opowiadania Rashomon po Uczte Babette. Na tych konwersatoriach z nas wszystkich tryskała energia, $\mathrm{z}$ niego także. Był młodym badaczem, dopiero co po stażu w IBL, pamiętam, jak gratulowaliśmy mu uzyskania tytułu doktora nauk humanistycznych.

Kiedy złożyłam egzamin magisterski, zaprzyjaźniliśmy się prywatnie. Spotykaliśmy się na seminariach w katedrze Pani Profesor Krystyny Poklewskiej (zaproszono mnie do uczestniczenia w nich, ale nie byłam pracownikiem UŁ). Te seminaria dały mi oparcie $w$ samodzielnym rozwoju i badaniach, ukształtowały w sposób, którego dobroczynne działanie odczuwam do dziś. W tamtych latach na mój rozwój miały wpływ dwa elementy: seminarium sanskryckie u Pana Magistra Sławomira Cieślikowskiego oraz seminarium Pani Profesor Poklewskiej. Oba dały mi bazę być może równie ważną co same studia. Dzięki seminarium z literatury porównawczej poznałam także środowisko, które ceniłam i którego potrzebowałam. Właśnie na tym seminarium poznałam śp. Krysię Ratajską, śp. Romka Kanarka (których nie znałam z uniwersyteckich zajęć), dzięki tym seminariom zaprzyjaźniłam się ze śp. Jolą Kordacką... Trudno jest teraz przywoływać owe czasy, gdyż niespodziewanie teraźniejszość zbyt zaczęła ranić tamte wspomnienia.

Z Jackiem spotykaliśmy się także poza uniwersytetem: u wspólnych przyjaciól, na konferencjach naukowych w hotelu uniwersyteckim na Rogach, w Arturówku i Łagiewnikach na długich spacerach, spotykaliśmy się w Tatrach, czasem wybieraliśmy się w dalsze podróże, odwiedzaliśmy się 
nawzajem. Rozwinęła się między nami głęboka przyjaźń, i duchowa, i intelektualna, i osobista, i naukowa.

Jacek lubił się dzielić myślami.

Owładnięty był podówczas, w końcu lat osiemdziesiątych, tematem milczenia Mickiewicza, milczenia u Mickiewicza. Poprzez fascynację figurą milczenia dochodził do metafizycznych w swym zakresie rozważań nad zwięzłością formy. Które z kolei wpisywały się w gorliwie przez niego odczuwany wewnętrzny nakaz rzetelności, pojmowany, wedle jego słów, za Jędrzejem Śniadeckim.

W czasie rozmów z Jackiem w jego domowym gabinecie gęstniał papierosowy dym i rosły sterty wyciąganych z półek książek. Pootwierane, szybko przestawały się mieścić na niezbyt dużym stole pełniącym funkcję biurka, schodziły na podłogę, wchodziły na tapczan. Jeśli bowiem rozmowy odbywały się w domu, bywały zazwyczaj ilustrowane odpowiednimi fragmentami tekstów. Jacek lubił książki mieć pod ręką. Jego gabinet obudowany był z trzech stron biblioteką, w której wiele półek dźwigało dwa rzędy tomów. Nawet jeśli chwile poszukiwania fragmentu się przeciągały, co nie należało do rzadkości, zawsze były one równie treściwe, co bezpośrednia wymiana komentarzy. Wtedy nie znaliśmy Internetu. Poszukiwanie samo w sobie mogło być celem i Jacek również tak je traktował.

Tym, co mnie do Jacka tak bardzo przywiązywało, była jego naturalna, instynktowna umiejętność łączenia materialnego, przyziemnego, sensualnego życia z aktywnością intelektualną, a sądzę, że należałoby ją określić jako duchową, wkraczającą w obszar metafizyki.

Około godziny 13 Jacek przerywał rozmowę, gasił papierosa. Milczał przez chwilę, potrzebną, aby wzrok z nieobecnego lub płonącego zamienił się w figlarny, i powiadał:

- Obiad.

Jacek lubił gotować.

Porzucaliśmy otwarte tomy i przenosiliśmy się na drugą stronę korytarza, do kuchni.

- Siadaj - mówił.

Kiedyś spróbowałam zaproponować pomoc, potem tylko siadałam na kuchennym stołku i biernie towarzyszyłam gotowaniu. Jacek często wkładał fartuch. Obierał ziemniaki, bił w kawałek schabu. Jeśli opowiadał mi o dzieciństwie, to właśnie wtedy. O tym, jak zawsze lubił ćwikłę, ale uciekał z kuchni w czasie jej przygotowywania, bo podczas tarkowania buraki pryskały wkoło na czerwono. Wspominał o lęku przed znalezieniem w ugotowanym kalafiorze robaka. W kucharskim fartuchu był uśmiechnięty, dowcipny, szczęśliwy i szalenie rozgadany.

Jeśli syn Jacka, Konrad, nie wracał zaraz ze szkoły, po obiedzie chadzaliśmy czasami na spacer. Nieruchome i często milczące skupienie nie wychodzi tak dobrze po posiłku jak na głodny żołądek; sjesta to czas na inne aktywności. To dobry czas na perypatetykę.

Jacek lubił chodzić. 
W lesie lub parku rozmawialiśmy najczęściej o Matsuo Bashō oraz poezji haiku. Obydwoje uwielbiający obcowanie z naturą podczas wspólnych spacerów próbowaliśmy patrzeć na nią poprzez filtr cudzej percepcji, między innymi dawnych japońskich poetów. Jacek był doskonale oczytany $\mathrm{w}$ dostępnych wtedy przekładach japońskich klasycznych haiku i znał teorię oraz historię tego gatunku. Cytował z pamięci utwory i posługiwał się japońską terminologią. To bywały często "chodzone seminaria” z przekładania świata na myśl oraz, oczywiście, na teraźniejszość. Percepcja się wyostrzała podczas takiej wymiany. Szukaliśmy wątków. Pojawiały się dosłownie wszędzie, na przykład na ścieżce w postaci żuka gnojownika albo motyla zderzonego z naszą wiedzą o jego krótkim życiu. A po zmroku w parku Julianowskim - w obrazie nieba i gwiazd odbijających się nisko w stawie, zderzonym z przypomnieniem zdania Kanta.

Czasami wybieraliśmy się gdzieś dalej, do innych lasów. Wtedy podjeżdżaliśmy najpierw samochodem; byłam szczęśliwą posiadaczką dzielnego małego fiata 126 p. Jacek nie miał jeszcze wówczas prawa jazdy. W tamtych latach bywało, że prowadziłam auto z młodzieńczą brawurą. Jacka nigdy to nie irytowało, lubił taką jazdę niczym łobuzerski chłopak. Pamiętam czas, kiedy zdecydował się samemu uzyskać prawo jazdy, przygotowywał się do egzaminu. Jeździliśmy więc niedzielami na duży pusty parking położony - jeśli mnie pamięć nie myli - na skraju Łagiewnik i ćwiczyliśmy. To znaczy Jacek siadał za kierownicą mojego „malucha”, ja obok. Wtedy się zżymał całym sobą, denerwował, sapał, dyszał i prychał. Wściekał się, nie słuchał korygujących poleceń, ale następnym razem okazywało się, że jednak szybko robi postępy.

Jacek miał serce do pracy fizycznej, do czynności manualnych, był silny jak tur i odporny na wysiłek. Zadanie fizyczne stanowiło wyzwanie, do którego podchodził z równym zaangażowaniem, co do obmyślania artykułu lub lektury. W końcu 1992 roku zmarł mój ojciec, z którym Jacek się znał i z którym nieraz spędzał godziny na rozmowie przy ognisku na naszej działce pod Łodzią. Po pogrzebie byłam otępiała, zdruzgotana, zagubiona, coś musiałam jednak uczynić w sprawie nagrobka. Jacek zaofiarował pomoc. W małej hobbystycznej stolarni, w ogrodzie u swego przyjaciela (albo członka rodziny?), który z pasją oddawał się stolarstwu, własnoręcznie, $\mathrm{z}$ niespożytą energią, wykonał dla mojego taty drewnianą skrzynkę nagrobną, po czym ją zamontował.

Był też towarzyski.

Pamiętam - jest luty przy końcu lat osiemdziesiątych - zachodzę do niego, zaproszona niewinnym: „Wpadnij na herbatę, pogadamy”, przy okazji jego imienin, a tam mnóstwo gości, siostra, kuzyni, zabawa w pełni. Ale jaka zabawa! Ze śpiewem, z ochoczym, wesołym „pociągiem”, obtańcowującym całą klatkę schodową w bloku. Jacek, basem rozśpiewany, porwał bez wyjątku wszystkich.

Kiedy wyprowadziłam się z Łodzi w 1994 roku, nie mogliśmy się spotykać tak często. Moja praca była absorbująca. W nim narastało zmęczenie ogromem bylejakości obecnej w świecie. I świadomością tej bylejakości. 
Próbowaliśmy rozmowy zamienić na korespondencję. Ale to nie było to samo.

Duchowe obszary, na które umiała wejść nasza rozmowa, z trudnością dawały się wyrazić na papierze. A to one stanowiły o istocie i mocy tej przyjaźni. Wiosną 1996 roku Jacek tak pisał: „....pisanie równoległe jest, naturalnie, niemożliwe. Pozostaje więc jedno: wyraźna, pełna i zupełna fragmentowość", a w innym liście z tego samego miesiąca:

Niezbyt potrafię zamienić rozmowę na rozmowę pisaną. Chyba nie umiem zgodzić się na taką zamianę [...]. Jest to bowiem w istocie odwrócenie czy postawienie na głowie naturalnego porządku rzeczy. Zakładamy również zgodę na - chcemy czy nie - pewną umowność. Wiem, że tej umowności niepodobna do końca ominąć, ale jakoś tak jest od pewnego czasu, że jej po prostu nie lubię. Drugi zaś powód byłby ten, że również od jakiegoś czasu mam niezbyt sprzyjającą pisaniu ideę absolutnej zwięzłości i jednocześnie poczucie sensowności milczenia [oba podkreślenia - Jacka].

Spędzając razem czas niejednokrotnie milczeliśmy.

Ale na odległość milczeć - wspólnie - się nie da.

Lata mijały. Korespondowaliśmy, choć coraz rzadziej, czasami rozmawialiśmy. Jacek pisał kolejne książki, ja jeździłam w związku z pracą po świecie, tłumaczyłam. Starzeliśmy się. Jackowi urodziły się wnuki, moja córka jest dorosła. Cały czas byliśmy przyjaciółmi i cały czas miałam świadomość, że Jacek zawsze mnie zrozumie, rzetelnie, głęboko, bezwarunkowo. Wtedy, kiedy nadejdzie potrzeba. Kiedyś...

Od jego śmierci myślę o nim częściej, niźli robiłam to przez ostatnie dwadzieścia lat. Świadomość tego, że żyje, wystarczała, by zakładać niezmienną możliwość rozmowy i życie codzienne toczyło się swoim osobnym torem. To było naturalne. Odkąd go nie ma, jest bardzo często obecny w moich myślach. To być może też naturalne, ale jednocześnie jakże bolesne.

Rzetelność. Głębia. Metafizyka. Rygor. Pasja.

Uczciwość.

Taki w moim wspomnieniu pozostaje Jacek, Profesor Jacek Brzozowski. 


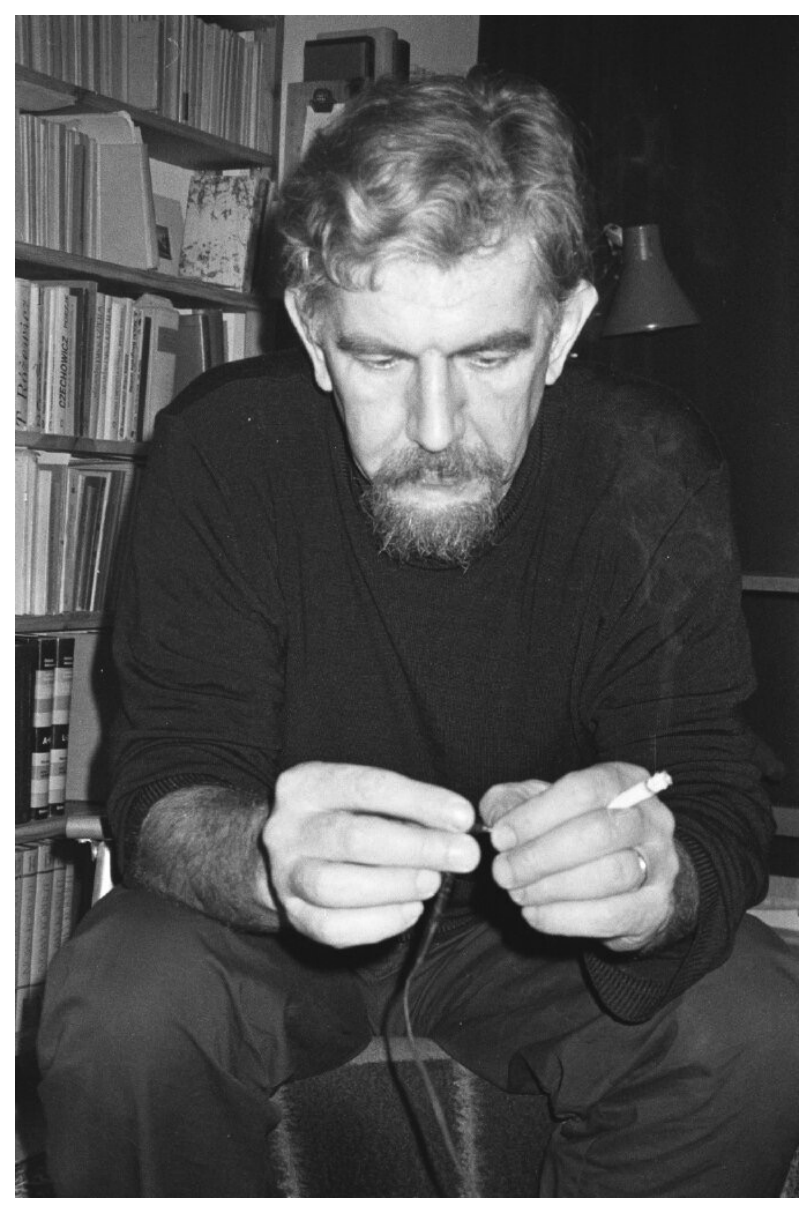

Jacek ok. 1989 roku, u siebie $\mathrm{w}$ domu, w gabinecie (z prywatnego archiwum Ewy Ledóchowicz) 



\section{Wspomnienie}

Kiedy myślę o profesorze Jacku Brzozowskim, zawsze najpierw widzę w pamięci młodego, energicznego i przystojnego adiunkta, którego poznałam w 1982 roku, gdy Uniwersytet Łódzki przygarnął mnie na etat po dyscyplinarnym zwolnieniu z kieleckiej WSP. W przyjaznej atmosferze katedry pani profesor Krystyny Poklewskiej odnalazłam swoje miejsce.

Mieszkałam w Warszawie, dojeżdżałam do Łodzi co tydzień, przez przeszło dziesięć lat. Nasza z Jackiem znajomość rozwijała się, rzec można, w godzinach pracy; i tematy z pracą związane stanowiły jej centrum. Nie sprzyjało to nawiązywaniu bliższych kontaktów towarzyskich, toteż niemal nie znaliśmy wzajemnie nawet swoich rodzin, choć często mówiliśmy o bliskich. Czasem razem z Jackiem odwiedzaliśmy jego żonę Ewę w jej biurze (i obiadowaliśmy w tamtejszej stołówce). Kiedyś, gdy miałam zostać do drugiego dnia, państwo Brzozowscy zaprosili mnie na noc.

To był początek przyjaźni także z Ewą. Później razem uczestniczyliśmy w konferencji poświęconej Słowackiemu w jubileuszowym roku 1999 w Wilnie; każdy uczestnik mógł, pokrywając koszty, dobrać kogoś z rodziny - z Jackiem oczywiście była Ewa. A ze mną wnuk, siedemnastoletni Karol, który, krytycznym okiem patrząc na mnie, a zachwyconym na Jacka, orzekł, że wreszcie widzi prawdziwego profesora, że Jacek Brzozowski jest jego ucieleśnieniem: wygląd, głos, postawa, zachowanie, sposób bycia... I trwał w tym podziwie.

Zwiedzaliśmy Wilno, trolejbusem pojechaliśmy do Trok; Karaimów, których chcieliśmy spotkać, było już niewielu, ale trwale pozostały ślady ich materialnej kultury i tamtejszego obyczaju. Nowy był tylko dumnie wznoszący się na wyspie wielki gotycki zamek (w miejscu dawnych malowniczych ruin), symbol potęgi dawnej Litwy; szło się długo ciągiem niemal pustych komnat.

Drugi raz byliśmy w Wilnie (lecz już bez członków rodziny) znów na konferencji, był też Marek Stanisz, wówczas młody adiunkt. Bardziej niż obrady utkwiła mi w pamięci podróż. Jacek postanowił jechać własnym autem i zabrał nas ze sobą (może z płonną nadzieją poznania przy okazji 
słynnego z literatury „litewskiego pejzażu”?), ale po drodze kilkakrotnie coś w samochodzie usterkowało, przystawaliśmy (może po prostu silnik musiał przestygnąć?); na szczęście nocą dojechaliśmy, zdążyliśmy uczestniczyć $\mathrm{w}$ obradach i po wizycie $\mathrm{w}$ warsztacie bez problemów wróciliśmy do ojczyzny. Po drodze gadaliśmy do woli - o wspólnej pasji: romantyzmie, i o własnych planach naukowych - wreszcie, w ciągu długiej podróży, był na to swobodny czas.

A potem co roku otrzymywałam podpisywane „Ewa i Jacek” wakacyjne dowody pamięci, widokówki z Tatr.

Najważniejsze nasze rozmowy dotyczyły możliwości poczynienia zmian w programie studiów i szkoły średniej - niezwłocznej aktualizacji wiedzy nauczycieli, konieczności uzupełniania obrazu tradycji oraz wprowadzania do kanonu lektur polskiej literatury współczesnej, „krajowej” i emigracyjnej. I powracało przede wszystkim pytanie o modernizację odczytywania romantyzmu, to wtedy wydawało się najważniejsze: w Polsce stanu wojennego dawne buntownicze i niepodległościowe ideały brzmiały tak pięknie i aktualnie!

Druga po romantyzmie naukowa miłość Jacka - współczesna poezja - interesowała mnie zdecydowanie mniej, ale sekundowałam przekonaniu o jej wielkim wpływie na umysły młodzieży, na ówcześnie tak ważną nośność przesłania moralnego. Konkretnym (choć nader skromnym) wspólnym owocem tych ideałów stała się opublikowana w szkolnym wydawnictwie "Stentor" mini antologia współczesnych polskich wierszy, zatytułowana Zaczynając od Miłosza. Dzięki Jackowi okazała się udana, na co w recenzji zwrócił uwagę Tadeusz Budrewicz, zaznaczając, że wybór wierszy został dokonany pod kątem uwypuklenia refleksyjnego nurtu w poezji współczesnej, podkreślającego „sposób reagowania na wyzwania rzeczywistości bardziej intelektualny niż emocjonalny, postawę wątpiącą, a nie wieszczą, $[\ldots]$ wiarę $\mathrm{w}$ sens uporczywego poszukiwania prawdy. Dialog ze światem jest tu więc również dialogiem $z$ tradycją"1. Świetnie uchwycił sens naszych ówczesnych dydaktycznych poczynań i nadziei.

Jacek Brzozowski swój życzliwy i entuzjastyczny stosunek do świata przekuwał energicznie na konkretną działalność, był otwarty na wszelkie propozycje ulepszeń naszej chropawej wtedy rzeczywistości. Gdy, już po 1989 roku, jeździliśmy po Polsce - w ramach działalności Stowarzyszenia Nauczycieli Humanistów "Prowincja” - z kursami Chrońmy elitę nauczycielska, uzupełniającymi ocenzurowaną na studiach i w szkolnym programie edukację humanistyczną, Jacek w ramach tej inicjatywy zorganizował (razem z Krystyną Pietrych) pierwszą konferencję naukową nauczycieli-humanistów. Tę konferencję współprowadzili nauczyciele, byli referentami; przedstawiali propozycje własnych interpretacji omawianych w szkole tekstów literackich.

Piękny był to pomysł, próba niwelacji istniejącej twardej granicy między działalnością nauczycielską a pracą naukową. Nawiązywano do tradycji

1 „Ojczyzna Polszczyzna” 1994, nr 1. 
- dawniej, dawno temu wybitni historycy literatury często rozpoczynali karierę od pracy w szkolnictwie: Juliusz Kleiner we Lwowie, Stanisław Pigoń w Krakowie, Czesław Zgorzelski w Wilnie... Jacek Brzozowski i Krystyna Pietrychowa zadbali o szybkie przygotowanie materiałów do druku i o książkową publikację - w 2005 roku ukazał się w Łodzi tom referatów Mickiewicz czytany w szkole. Mieliśmy złudną nadzieję, że może uda się tę tradycję reanimować i utrwalić, wspomagając naukowe ambicje nauczycieli. Konferencja się udała, ale nie podjęto jej kontynuacji. Niestety, zawodowe przeciążenie i nadmierny rygoryzm całkowitego podporządkowania pracy nauczycieli realizacji szkolnego programu ogranicza do minimum możliwości rozwijania ich własnych pasji intelektualnych - może kiedyś...

Jacek miał niezwykły dar słowa, przekonywania. Gdy mówił, czy to o współczesnej poezji, czy o romantykach, czy o lirykach lozańskich, mówił tak mądrze i żarliwie, że każdy temat okazywał się fascynujący, a każda wątpliwość warta głębszej refleksji - cóż może kryć się za słowami o ucieczce duszy na listek? Jak snuje się miłość - z siebie czy sobą? „Rozwijać” miłość - czy skryte pod kleksem słowo należy odczytywać raczej jako „rozkuwać”, a to przecież coś wręcz odwrotnego znaczy? Ileż wyłania się tu rozmaitych możliwości nadających sens drobiazgom. Lektura tak uważna i dociekliwa była wyrazistym rysem postawy badawczej profesora Brzozowskiego (dzielił je może tylko z Józefem Bachórzem). Chętnie aprobując zdanie innych, otwierał drogę przed możliwą wielością odczytań utworu. Bo u profesora Brzozowskiego z reguły drobna wątpliwość, nawet korekta pojedynczej litery, wiodła ku przeistaczaniu odnajdywanego sensu. Przemieniał tym samym rolę wyznaczaną historykowi literatury: szedł drogą raczej rewizji dotychczasowych ustaleń niż kontynuacji „udoskonalającej”, wpajał nie tylko wiedzę, nie narzucał gotowych rozwiązań, lecz dyskutował, przede wszystkim słuchaczy intelektualne pobudzał, zmuszał do samodzielnej refleksji, do lektury "prywatnej”.

Wielkiej trzeba było determinacji i odwagi, by rozpocząć nową krytyczną edycję dzieł Słowackiego. Pozostała po poecie ogromna rękopiśmienna spuścizna, wyjątkowo trudna do ogarnięcia i sensownego uporządkowania. Profesorowie Jacek Brzozowski i Zbigniew Przychodniak podjęli to wyzwanie monumentalne - i fascynujące.

Wcześniejsze wydanie krytyczne, opracowane przez Juliusza Kleinera, po upływie ponad pół wieku okazało się niewystarczające, edytorskie dzieje Beniowskiego są tego najlepszym przykładem. Kleiner rozdzielił tekst poematu między trzy z siedemnastu tomów Dzieł wszystkich, pieśni publikowane za życia ulokował w tomie 5 (pośród innych utworów!), w innym woluminie pieśni kolejne, a w jeszcze dalszym fragmenty o nieustalonej przynależności.

Brzozowski i Przychodniak przyjęli odmienną koncepcję, skonsolidowali całość dzieła, trzon główny z odgałęzieniami i kontynuacjami, w jednym wielkim tomie. Ta decyzja ostatecznie uwypukliła rangę Beniowskiego pośród dorobku arcypoety i odsłoniła nowe, różnymi wersjami rzutujące 
w przyszłość, perspektywy interpretacyjne. Odsłaniały je również wielkie ilości drobnych zmian, zawsze szczegółowo uzasadnianych.

Nie tu miejsce, by zatrzymywać się nad walorami ujętej w cztery tomy nowej edycji krytycznej poezji Słowackiego. Jedno natomiast zawsze mnie zachwycało w naukowej pracy Jacka Brzozowskiego: piękny (i dostosowany także do poziomu normalnego odbiorcy) język jego naukowych tekstów; i równie piękna, pełna rewerencji postawa i szacunek okazywany poprzednikom, dawnym mistrzom. Zawsze miałam wrażenie, że cieszą go tak własne, jak i cudze osiągnięcia i że na tym polega kultura pracy naukowej.

Po moim odejściu z Łodzi twórczość Słowackiego pozostała najmocniejszą więzią przyjaźni z Jackiem (a przez niego, pośrednio, także ze Zbigniewem Przychodniakiem; mieszkał aż w Poznaniu, był rzadziej dostępny). Te rozmowy zaowocowały powierzeniem mi wydawniczej recenzji ich dzieła.

Dumna jestem z dedykacji zdobiącej mój egzemplarz pierwszego tomu krytycznej edycji: „Drogiej Alinie - z serdecznością i wdzięcznością największą Jacek Brzozowski, Zbigniew Przychodniak, Poznań-Łódź, 20 września 2005".

Moje pożegnanie z IBL-em uroczyście uczczono wspaniałą księgą pamiątkową, redagowaną przez trzech przyjaciół: Jacka Brzozowskiego, Mirka Skrzypczyka i Marka Stanisza. Wielkie dzieło, na którego przygotowanie poświęcili mnóstwo czasu i trudu, i (co rzadko się udaje) utrzymali je w tajemnicy przede mną do ostatniej chwili. Cóż to była za niespodzianka!

Ostatnie spotkanie. Poznań, listopad 2015. Jacek zmierza na obiad do Puszczykowa, do państwa Przychodniaków. Ściągają i mnie, urocze popołudnie. Umawiamy się, nieobowiązująco, na następny raz. Odwożą mnie do pociągu. Jacek jeszcze zostaje, do jutra.

Wszystko, co tu zapisałam, to drobiazgi, z jakichś powodów pozostałe w pamięci. Zastępują ułomnie to, co w przyjaźni naprawdę było i jest ważne - i co tak trudno słowami wyrazić. 


\section{"Daję wain \\ tę ostatnią koronę pamiątek..."}

Profesor Jacek Brzozowski w ostatnich latach pośród wielu swoich prac - a wiem dobrze: przez dwadzieścia lat widziałem z bliska, jak intensywnie i jak owocnie pracował - zajęty był dwoma wielkimi pracami w przestrzeni pisarskiej Juliusza Słowackiego. Od roku 2015 należał do zespołu grantu NCN kierowanego przez profesor Marię Kalinowską na Wydziale Artes Liberales Uniwersytetu Warszawskiego, przygotowującego edycję naukową odnalezionego raptularza Juliusza Słowackiego z podróży na Wschód. Razem badaliśmy kilkanaście wierszy zawartych w tym bezcennym dokumencie - w większości nieopublikowane przez poetę, znane dotąd tylko z dawnych edycji i reedycji dokonanych przez wydawców mających dostęp do rękopisu przed jego zaginięciem w roku 1939. Raptularz wschodni służył Słowackiemu w podróży za notes podręczny, szkicownik reportera i brulion poety z zapisem ulotnych wrażeń i duchowych doświadczeń. Wśród wierszy znajdujemy tutaj pięć [Listów poetyckich z Egiptu], Pieśn na Nilu, [Rozmowe z piramidami], dwa wiersze związane z religijnym przeżyciem wizyty u Grobu Zbawiciela w Jerozolimie: I porzuciwszy droge światowych omamień... oraz Czyż dla ziemskiego tutaj wojownika... Nasza praca - w pewnym stopniu oznaczająca powrót do edytorskiego opracowania z czasu przygotowywania edycji krytycznej wszystkich wierszy Słowackiego z 2005 roku (praca edytora nigdy się nie kończy...) - polegała przede wszystkim na żmudnym odczytywaniu gęsto kreślonych, brulionowych wpisów poety (nikt lepiej od Jacka nie znał pisma ręką Słowackiego!), analizie tradycji edytorskiej poszczególnych utworów i sporządzeniu wersji zapisu w transliteracji i transkrypcji. Szczęśliwie zdążyliśmy razem wykonać główny zrąb pracy rekonstrukcyjnej. Niestety, ostatecznego efektu, reprintu całości raptularza oraz jego podwójnej redakcji w transliteracji i transkrypcji - planowanego na rok 2018 - Jacek już nie zobaczy.

Od roku 2016 byliśmy zaangażowani w kolejnym grancie Narodowego Programu Humanistyki przyznanym na kontynuację nowej edycji krytycznej 
dzieł Słowackiego. Tym razem, po Wierszach (2005), dwóch tomach Poematów (2014) i całości Beniowskiego, otrzymaliśmy zadanie największe i najtrudniejsze: zbadać i opracować na nowo spuściznę rękopiśmienną i edytorską poematu historiozoficznego Król-Duch. Podejmując się tego zadania, przyjęliśmy dwa pragmatyczne założenia. Pierwszym była nadzieja na pogodzenie niezwyczajnych wymogów „filologii genezyjskiej” (która bodaj samemu poecie wymknęła się spod kontroli) z modelem edycji wypracowanym przy pracy nad poznańskimi tomami wierszy i innych poematów Słowackiego. Aparat krytyczny "poznańskiego" nowego wydania budowano z myślą o tym, by był pełny, wyczerpujący, a zarazem maksymalnie "przyjazny" dla czytelnika, klarowny i przejrzyście podany. Zasadę drugą stanowić miało odejście od reguły edytorstwa interpretującego, teleologicznego, dążącego do rekonstrukcji dzieła finalnego, ostatecznego. W praktyce dotychczasowej, na przykład w Kleinerowskiej edycji Dzieł wszystkich, prowadziło to do heroicznych prób porządkowania fabularnej struktury Króla-Ducha - z tekstem głównym i gąszczem redakcji, wariantów, odmian. Wariantowość i amorficzność pozostaje cechą niezbywalną poematu Słowackiego. Uznaliśmy, że konieczne jest odejście od utopii dzieła finalnego na rzecz zasady genetycznej, inspirowanej ideami francuskiej krytyki genetycznej, lepiej oddającej wielowariantowość ostatniego wielkiego dzieła Słowackiego. Chodziło o to, by jak najmniej ingerować w amorficzną i polimorficzną strukturę Króla-Ducha, jego rozgałęzień, powtórzeń, wariantów. Zamiast linearnej hierarchizacji zaproponować otwartą strukturę warstw genealogicznych, równoległych.

Praca nad nową edycją Króla-Ducha zaplanowana była na dobrych kilka lat. W ostatnim roku, mimo choroby Jacka, nie zaniechaliśmy tego zamysłu. Los zdecydował inaczej. Nie pozwolił Jackowi przejść całej drogi Słowackiego: od wierszy przez poematy (i Beniowskiego) - do Króla-Ducha. Dzieło niedokończone i dzieło niewydane. Nieoczekiwana paralela losu przedwcześnie zmarłego poety i przerwanej biografii edytora.

Jacek Brzozowski był znakomitym interpretatorem liryki polskiej. Znał i głęboko rozumiał poetyckie idiolekty rodzimych twórców - od Kochanowskiego i Morsztynów do Słowackiego i Mickiewicza, od Staffa i Leśmiana do Szymborskiej i Herberta. Na mocnym fundamencie gruntownie przebadanej tradycji klasycznej (czego dowodem jest podoktorska książka Muzy w poezji polskiej z roku 1986) zbudował rozległy gmach znaczeń odczytanych poezji polskiej. Pojęcie „odczytywania” jest kluczem do Jego sztuki interpretacji, której początek wyznaczało uważne odcyfrowywanie rękopisów, śledzenie zmian tekstologicznych. Potwierdzeniem tego są jego publikacje: książka Odczytywanie znaczeń. Studia o poezji Mickiewicza (1997) oraz dwa tomy Odczytywania romantyków (2002, 2011). Co równie znamienne, w tytułach i podtytułach Jego książek powtarzają się określenia gatunkowe z liczebnikiem: "dwadzieścia dwa szkice i notatki”, „dwanaście szkiców i komentarzy”, "11 szkiców o czytaniu wierszy”. To nie tylko wyraz szczerej retoryki skromności. W swoim czytaniu poezji polskiej Profesor Brzozowski nie silił się na wielkie syntezy i uogólnienia, starał się 
być maksymalnie konkretny i rzeczowy. Głębokie sensy utworu wyprowadzał z najdrobniejszych szczegółów rękopisu, odczytań tekstu, niuansów językowych każdego wiersza, każdego słowa. Nie znaczy to, że obcy był Mu duch myślenia monograficznego i syntetycznego. Zmysł syntezy i panoramiczny ogląd filologa uruchamiał w pracy edytorskiej, doskonale panując nad całością tekstowych światów poetyckich. Notabene, do wybitnych prac edytorskich Jacka Brzozowskiego należy również "potrójna” (reprint autografu, transliteracja, transkrypcja) edycja Słowackiego [Dziennika z lat 1847-1849], wzorowo wykonana wraz z Katarzyną Szumską (2012).

Te dwa sposoby lektury dzieła poetyckiego, filologiczno-edytorski $\mathrm{i}$ interpretacyjny, wzajemnie się dopełniały $\mathrm{i}$ uzupełniały $\mathrm{w}$ przedsięwzięciach naukowych Jacka. Interpretatorska wrażliwość na pojedyncze słowo poetyckie wręcz predestynowała Jacka do żmudnej roboty filologiczno-edytorskiej. Ta praca zajęła przeważającą część ostatnich dwudziestu lat życia Jacka. Ale działało to również w odwrotnym kierunku: praca edytorska dostarczała nowych inspiracji i zachęt na polu sztuki interpretacji. Dowodem niech będzie skromna, wydana własnym sumptem książeczka Parerga edytorskie (Z prac nad tekstami Juliusza Stowackiego) (2013), gdzie odczytywanie rękopisów autora Beniowskiego, tropienie błędnych lekcji i odmiennych redakcji, niefortunnych pomyłek edytorskich i innych tego rodzaju "drobiazgów”, zawsze w ostatecznym rachunku służyło głębokiemu, rozumiejącemu odczytywaniu poezji. A dzisiaj - śmiem sądzić - tytułowe określenia odnoszące się do konkretnych przypadków edytorskich mają siłę... poetyckich ekspresji. Sięgam po kilka z artykułu Notatki do lektury wierszy [Stowackiego]: „Wątpliwa poprawka”, ,Zagubiony sens”, „Łzy źródlanej wody”, „Pechowy epigramat”.

Jacek miał ulubionych poetów: czytał stale Różewicza i Szymborską, wracał do poezji Mickiewicza i Słowackiego. Nie darzył sympatią Krasińskiego. Nie chodziło o szukanie wad charakteru; cenił taką poezję, w której odnajdywał głęboką prawdę poświadczoną życiem poety. Powracał do liryków lozańskich Mickiewicza. Postrzegał je jako całość, ale o każdym z utworów tego niezwykłego cyklu napisał osobny szkic-esej interpretacyjny. Widział w nich "poetycki i życiowy bilans, nieledwie testament” (Odczytywanie romantyków 2, s. 50), "liryczny autoportret” Mickiewicza (s. 62), głos daleko wybiegający w przyszłość poezji. Pisał o „obrazie autora w lirykach lozańskich", o symbolice domu w wierszu Ach, już $i$ w rodzicielskim domu... i w urywku Uciec z dusza na listek..., badał "rymy częstochowskie” wiersza Polaty się tzy me czyste, rzęsiste..., dodawał kolejne glosy "na marginesie wiersza Snuć miłość...". Miałem okazję, w trakcie wspólnych kwerend paryskich w Bibliotece Polskiej, obserwować, jak bacznie, przez szkło powiększające, badał autografy wierszy wpisane przez Mickiewicza drobnym pismem na „złożonym wpół arkusiku” o wymiarach 16,7 × 10,3 centymetrów, przechowywanym w Bibliotece Polskiej.

Jacek planował w przyszłości osobną książkę o lirykach lozańskich. Odpowiedź na to pytanie o powody tak częstego czytania wierszy lozańskich dał 
w zakończeniu jednego z tych szkiców: „Jeśli na koniec miałbym powiedzieć, co każe mi powracać do Mickiewicza, to właśnie ta od jego słów nieoddzielna prawda. Prawda Poezji, nie literatury. Poezji, w której ważne jest każde słowo" (Odczytywanie romantyków 2, s. 88).

Podobnie czytał testy Słowackiego. Badał główne wątki lirycznych narracji autora Godziny myśli; tropił, choćby najdrobniejsze (przez to właśnie znamienne, najszczersze), ślady i krystalizacje przeżyć egzystencjalnych poety. Pisał o "domowych marzeniach mistyka”; doskonale ukazał bogactwo kulturowych odniesień i intymny wymiar mistycznego doświadczenia w wierszu Zachwycenie. Sporządzał precyzyjne i sumienne "notatki do lektury wierszy" Słowackiego (tytuł szkicu z 2010 roku). Odsłaniał tajemnice i lęki chorego śmiertelnie poety. Dzisiaj w szczególności przyciągają moją uwagę przenikliwe, wyjątkowo obszerne jak na Jacka (cenił lapidarność, nie lubił form rozwlekłych), prawie trzydziestostronicowe Uwagi, dla których powodem byt wiersz „Daję wam tę ostatnia koronę pamiatek...". Jacek zebrał w tym szkicu niemal antologię obsesyjnie powracających motywów i obrazów śmierci zaczerpniętych z listów Słowackiego, pokazał przemianę duchową poety po roku 1842, gdy w obliczu genezyjskich rewelacji twórca zanegował sens biologicznej śmierci, wybrał postawę „ufnej i pewnej wiary, spokój, nieledwie obojętność" (Odczytywanie romantyków, s. 245). W raptularzowym liryku Słowackiego z lat ostatnich Jacek Brzozowski odsłonił wyjątkowy moment autorefleksji poety, złączenia się dwóch wymiarów życia: metafizycznego, absolutnego, i najzupełniej realnego, cielesnego. Moment zderzenia wielkich marzeń („Dawniej myślałem rzeczy uczynić szalone”) z brutalną realnością, chwilę rezygnacji i uspokojenia: „Lecz mi teraz wystarczy mały ziemi kątek / Gdzie w deskowej się zawrę muszli i utonę".

Jacek nie szukał $\mathrm{w}$ poezji łatwych pocieszeń ni moralnych satysfakcji. Wierzę głęboko, że trwać będą „pamiątki”, które zostawił. Jacek był - jest i pozostanie - częścią mego życia. Współpracownikiem, Powiernikiem, Przyjacielem. Nie potrafię inaczej Go w tej chwili pożegnać, jak słowami z innego wiersza Juliusza Słowackiego:

\footnotetext{
Zatchnął się cały świat - i wszystkie gaje

Zabrzęczały... a echa zbudzone pieśniami

Poszły tam - gdzie my życiem znużeni i sami

Pójdziemy... w ciemną mgłę - gdzie słońce wstaje.
} 


\section{Profesorze \\ Jacku Brzozowskim wspomnienie}

Będzie to raczej dotknięcie serdeczną myślą niż wspomnienie, które się przywołuje, choć bywa, że ono samo przychodzi. Dotyka się bowiem ludzi, rzeczy i spraw, które są blisko i zostawiają trwały ślad.

Zebrało się zaś wiele, niejednakiej dotkliwości, takich śladów albo samobieżnych wspomnień. Z dziejów wspólnego pełnienia funkcji dziekańskich na Wydziale Filologicznym Uniwersytetu Łódzkiego, czytania i recenzowania Jacka prac, z zasłuchania na Jego wykładzie habilitacyjnym i różnych (Jego) wystąpieniach, z niepoliczonych spotkań, narad, rozmów, wzajemnych decyzji, notek mejlowych, z dochodzących oddźwięków. Całość byłaby trudna do ogarnięcia i teraz niepotrzebna. Zachowam coś, nawet kruszywo, tylko dla siebie. Kruszcem i może sekretem chętnie się podzielę, dotykając spraw rozmaitych. By się ukazał choć zrąbek rozmaitości stworzenia.

Warto pamiętać, że na osiągnięty w 2006 roku wysoki status Wydziału Filologicznego: „w kategoryzacji jednostek naukowych najwyższą pozycję [...] kategorię pierwszą" ${ }^{1}$, Jacek niemało zapracował, pełniąc funkcję prodziekana (2002-2005). Niemało było wyzwań i przygód, także przykrych i nieomal humorystycznych, z którymi się wtedy zmierzył. Adwersarze (niejedni do dziś nie wiedzą, ile dobrego byłemu prodziekanowi zawdzięczają) i sympatycy mogliby wiele opowiedzieć. Spodziewałem się i myślałem - bynajmniej nie marząc - że będzie nieocenionym kandydatem na urząd dziekana. Niełaskawe dlań „szlachetne zdrowie” ucięło wątek. Ale i z tego na korzyść wyszło, bo więcej mógł się oddać swej pasji naukowej, uprawianej z charyzmą akademicką i wysokim etosem akademickim. Nie są to za wielkie słowa. Obie cechy były widoczne u Jacka w sprawach wszelakiej wagi, także z dystansu na pozór marginalnych. Jego zaś te właściwości wcale nie

${ }^{1}$ W. Puś, Zarys historii Uniwersytetu Eódzkiego 1945-2015, Łódź 2015, s. 155. Autor tej książki pełnił wówczas funkcję rektora UŁ. 
usztywniały. Wprost przeciwnie, czyniły człowiekiem żywym, jakimś wichrem wewnętrznym porwanym (bo inwencyjność miał jakby w genach), stanowczym, do bólu pryncypialnym w słusznej, jak się oczywistością lub argumentacją narzucało, sprawie. Stąd się czasem brały kolizje Jacka z rzeczywistością daleką od ideału... Ale nie było stąd żadnej niekonsekwencji $\mathrm{w}$ decyzjach. $Z$ promotorem nad podziw dobrej pracy magisterskiej, zgłoszonej na konkurs wydziałowy, byliśmy obaj wielokroć skonfliktowani. Nieważne jest, kto w sporach miał rację. Też mogliśmy pobłądzić. Nie patronowało nam poczucie nieomylności. Funkcje dziekańskie nieraz wymagają szybkiej i bezkompromisowej reakcji, a był to okres permanentnego przyśpieszenia. Oddawane w konkursie głosy nie wskazywały, że zostanie wyróżniona wyborna jakość. Mogło wygrać małe środowiskowe lobby. Szalę przeważyły nasze głosy. Jacek stwierdził, że niewiele temu magisterium brakuje do rozprawy doktorskiej. Z promotorem pracy był w permanentnej niezgodzie. Niekiedy wzywano mnie, bym jak zacietrzewionych bokserów rozłączał ich w... wymianie zdań. Uszanował jednak prowadzącą rękę naukowego mistrza i świetny rezultat uczniowskiej roboty. Tak optując, nie był utrapiony. Mnie się ten ślad wyraźniej od innych zapisał.

W telewizyjnych Milionerach są tak zwane koła ratunkowe. Wśród nich często zawodzi "telefon do przyjaciela”, nie zawsze kompetentnego. Tak bywa również $\mathrm{w}$ realu, ale mnie telefon do Jacka nigdy nie zawiódł. Na jeden $\mathrm{z}$ kłopotliwych odpowiedział $\mathrm{w}$ dwóch szybkich mejlach, chronologicznie do mnie ostatnich (z 11 marca 2017). Poradził w epistolograficznej sprawie, nieobjaśnionej kompletnie nawet w wydaniu rocznicowym Dzieł Adama Mickiewicza (red. naczelna: Zbigniew Jerzy Nowak, Maria Prussak, Zofia Stefanowska, Czesław Zgorzelski, t. 1-17, Warszawa 1993-2005), które jako recenzent nazwał „pod wieloma względami wybitnym” ${ }^{2}$. Otóż bardzo skrupulatny chiński polonista, tłumaczący listy naszego wieszcza, chciał wiedzieć więcej niż polscy edytorzy. Nie potrafiłem pomóc. Jacek ekspresowo poratował. Będzie miał zasługę $\mathrm{w}$ tłumaczeniu na język chiński listów Mickiewicza. Zresztą na antypodach dobrze już znakomitego nie tylko warsztatowca znają. Jego współautorską edycję wierszy Juliusza Słowackiego podarowałem profesor Yi Lijun z okazji nadania jej tytułu doktora honoris causa Uniwersytetu Gdańskiego (2007).

Wiele prac Jacka Brzozowskiego czytałem i recenzowałem. W recenzji do wniosku o tytuł profesora podziwiałem literaturoznawcze pisarstwo oparte "na wyjątkowo rozległej i konstruktywnej (bo funkcjonalnej) erudycji, obejmującej podstawy i niuanse polonistycznego warsztatu oraz inwencyjnie dokomponowane przyległości; na słowie od razu celnym albo cierpliwie drążącym istotę rzeczy"; podziwiałem tezy wybijające się "jasno, przekonująco i... odkrywczo". W rekapitulacji wniosku złamał się mój recenzencki rygor - jak teraz zdyscyplinowana myśl nieco się łamie - na rzecz utrudzonego człowieka, nienasyconego dążeniem naukowym, łaknącego

2 „Pamiętnik Literacki” 2009, z. 4, s. 187. 
nowych wyzwań, ale może i jakiegoś spokoju. (Podobnego przykładu na literaturoznawczym podłożu nie znam... poza tym jednym). Wiem, że trafiłem wtedy w skryte rzeczy sedno, w Jego oczekiwania, słowami:

Nie dla środowiskowego uznania (notabene, było wysokie na zebraniu działającej przy Towarzystwie Literackim im. Adama Mickiewicza krajowej Komisji Edytorskiej, której przewodniczyłem) ani dla nagrody naukowej, choćby najwyższej, wykonuje się takie prace. Przecież J. Brzozowski, postrzegany przez pryzmat autorskiego wkładu do edycji Wierszy, miałby prawo ujęciami Słowackiego określić własną rolę i oscylujący między biegunami charakter wypełnionego zadania (jako: „ziemski [...] wojownik”, „dni najemnika”, „sługa”, „robotnik”), zostawiając domysłom, poprzez identyczne językowe pośrednictwo, że jeszcze - a według mego przekonania, zasadnie - „czeka swej zapłaty"3.

Zapewne chciałoby się wiedzieć i powiedzieć dużo więcej o Jacku Brzozowskim. Jednego mojego serca będzie mało. Nie wątpię, że inne dobiegną i wyprzedzą.

${ }^{3}$ Mikrocytaty z wiersza Czyż dla ziemskiego tutaj wojownika..., według: J. Słowacki, Wiersze. Nowe wydanie krytyczne, oprac. J. Brzozowski, Z. Przychodniak, Poznań 2005, s. 187. 

Zanim spotkałam Jacka Brzozowskiego, był dla mnie postacią z książek, znałam go bowiem jako edytora i autora znakomitych tekstów interpretacyjnych, szczególnie zaś pracy o muzach w literaturze polskiej. W związku $\mathrm{z}$ tym, że pracowałam nad rozprawą poświęconą topice muz $\mathrm{w}$ romantyzmie, była to dla mnie pozycja zasadnicza, bezcenne źródło wiedzy i punkt wyjścia do własnych badań. $Z$ przejęciem czekałam zatem na spotkanie, które miało miejsce $\mathrm{w}$ Toruniu, na konferencji poświęconej poematom dygresyjnym Słowackiego (w jubileuszowym roku 2009), podczas której oboje wygłaszaliśmy referaty. $Z$ pewną nieśmiałością podeszłam do niego w kuluarach, mówiąc, zapewne niezbyt fortunnie: „Panie Profesorze, przyszłam złapać Pana za muzę". Profesor uśmiechnął się z zaciekawieniem i tak rozpoczęła się nasza rozmowa. Rzadko zdarza się, że nawiązujemy z kimś nić porozumienia natychmiast, od pierwszych słów. Wtedy tak właśnie się stało. Jacek Brzozowski był pod tym względem wyjątkowy, miał rzadką otwartość na drugiego człowieka i szacunek do każdego rozmówcy.

Potem spotkaliśmy się wielokrotnie z racji wspólnych obszarów badawczych i pełnionych funkcji; Profesor był recenzentem mojej habilitacji, a w tym roku także mojej książki Romantyzm, czyli inter esse. Wspominam o tym, bo ta jego recenzja, bardzo dla mnie cenna, jest prawdopodobnie jednym z ostatnich tekstów, jakie napisał. $\mathrm{Z}$ racji tego, czym się zajmuję, szczególnie ważne było dla mnie - i wciąż jest - to, co i w jaki sposób mówił o romantyzmie, o Słowackim, Mickiewiczu, Norwidzie jako pisarzach istotnych dzisiaj dla nas, dla naszej nowoczesności, których warto czytać wciąż na nowo (myślę tu szczególnie o pracy w zespole badawczym zajmującym się podmiotowością (po)romantyczną).

Zawsze wnikliwy, uważny, oddzielający to, co ważne, od tego, co nieistotne, niezakładający własnej nieomylności. Tak go pamiętam. Najważniejsze jest dla mnie jednak wspomnienie rozmów z Jackiem, także tych telefonicznych, bo miał zwyczaj dzwonić zawsze, kiedy pojawiały się jakieś pytania czy wątpliwości, ale zwłaszcza tych twarzą w twarz. Można było z nim rozmawiać rzeczywiście o wszystkim, zwłaszcza o tym, co go 
poruszało, a nie był obojętny na to, co dzieje się wokól, angażował się całym sobą.

Także o literaturze mówił właśnie tak, że wiadomo było, że go porusza, że to, co mówi, to nie jest jakaś zasuszona wiedza, ale coś istotnego, żywego, co nieustannie go zadziwia. By było jasne, jego entuzjazm nie miał nic wspólnego z pustą emfazą. Oparty był zawsze - tu ujawniała się edytorska skrupulatność Profesora - na szczególe, konkrecie, kontekście. Te zadziwienia, odkrywania dla siebie wciąż nowych wymiarów literatury i pragnienie podzielenia się tym odkryciem z innymi, były i są podstawą wspólnoty interpretacyjnej. Z Jackiem taka autentyczna wspólnota nie była mrzonką, stawała się możliwa. Jestem wdzięczna, że dane mi było w niej uczestniczyć. 


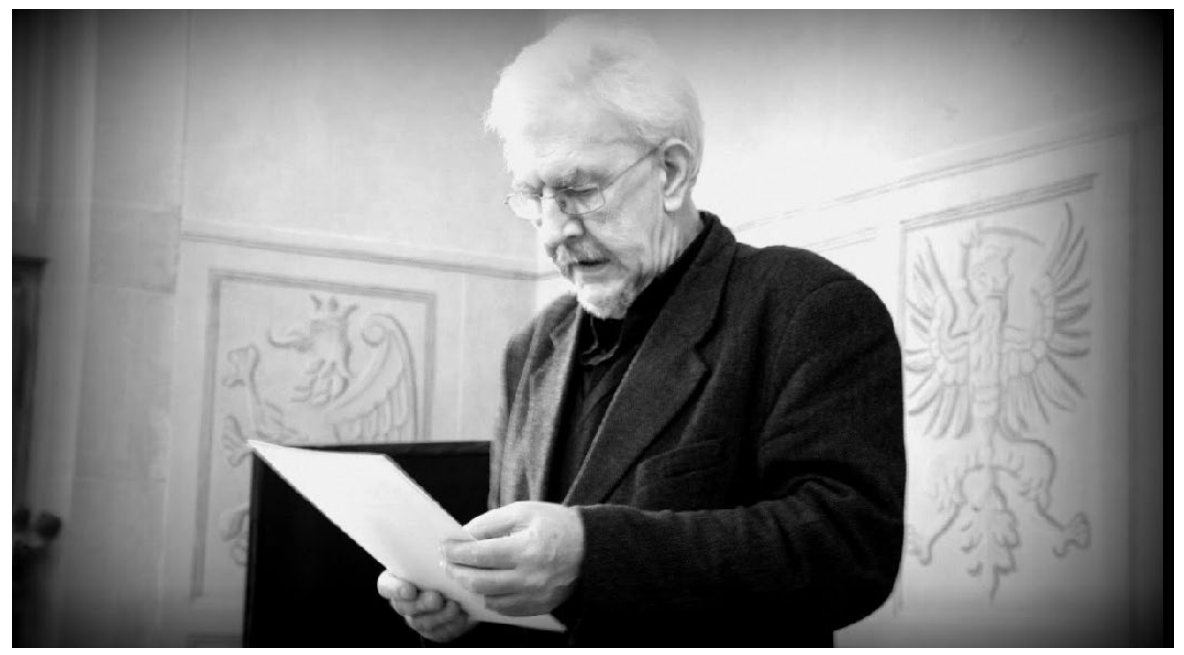

Prof. Jacek Brzozowski wygłasza referat podczas obrad plenarnych konferencji naukowej Norwidowski Świat Rzeczy w Toruniu (4 grudnia 2014 roku) 



\section{Wspomnienie \\ o Profesorze Jacku Brzozowskim}

Trudno wspominać Profesora - tacy ludzie przecież nie umierają. Bardzo energiczny, charyzmatyczny, pełen życia. Trudno wspominać, bo Profesor to cały wachlarz emocji, które pojawiają się wraz z napływającymi obrazami: pierwsze ćwiczenia z literatury romantyzmu, które prowadził wówczas jeszcze doktor Jacek Brzozowski, i zaskoczenie: „To tak można mówić o wieszczach?!”; egzamin z literatury romantyzmu w kłębach dymu tytoniowego: „No tak, no tak, pani Katarzyno, naprawdę Lambro się pani nie podobał? No to porozmawiajmy o tym"; Jego stanowczość i współczucie w czasie bardzo emocjonalnego wykładu o Słowackim tuż po tragicznych juwenaliach na Lumumbowie. I wreszcie: wyjątkowe, entuzjastyczne seminaria magisterskie - pracowałam z fantastyczną grupą, zmotywowaną, zawsze dobrze przygotowaną, tak żeby Profesorowi nie udało się nas zagiąć; ciągle mam przed oczami Profesora gwałtownie podskakującego na krześle, kiedy mówił o Leśmianie (były zakłady przed seminarium, czy krzesło wytrzyma), dyskusje trwały tak długo, że rzadko kiedy zajęcia kończyły się o wyznaczonej porze, zawsze żal było wychodzić. I ten zapach tytoniu na pokreślonych na czerwono stronicach pracy magisterskiej. Nie zapomnę trudnego okresu redagowania Dziennika Słowackiego, satysfakcji ze śledczej niemal pracy nad jego rękopisem, długiego milczenia Profesora i wspólnej radości, kiedy odkryłam błąd popełniony przez poetę, burzliwych kłótni o przecinki i wielkie litery. Najtrudniejsze emocje to te obecne - smutek i poniekąd złość, że nie dokończymy już kilku ważnych rozmów, że już nie powie: „Pani Katarzyno, niechże mnie pani posłucha”.

To zaszczyt i szczęście spotkać na swojej drodze takiego Nauczyciela - wyrozumiałego, cierpliwego, zawsze bardzo uważnie słuchającego i czytającego, czasem upartego, złośliwego, ironicznego, ale tak życzliwie, z troską o swoich uczniów. Jestem wdzięczna Profesorowi za pomoc, za zarażenie mnie pasją edytorską i zwrócenie uwagi na to, jak ważne w literaturze są drobiazgi. Nie mam odwagi wykasować z telefonu numeru Profesora, 
ciągle jeszcze wyświetla mi się ostatnie połączenie. Panie Profesorze, dziękuję również za tę najważniejszą, najtrudniejszą lekcję - lekcję odchodzenia z godnością, z szacunkiem do ludzi i do pracy, z dystansem do własnej choroby: „No, pani Katarzyno, to nie duch do pani dzwoni, z żywym pani rozmawia". 


\section{Wspomienie \\ o Profesorze Jacku Brzozowskim}

Jako studentka drugiego roku polonistyki zaczęłam uczęszczać na wykład z literatury romantyzmu. Pierwsze zajęcia były jednocześnie moim pierwszym spotkaniem z Profesorem. Z każdą minutą wsłuchiwałam się w jego słowa z coraz większym zdumieniem i zaangażowaniem. „Nie do wiary, że ktoś potrafi tak mówić!” - pomyślałam wtedy. I myślę tak nadal, bo doprawdy nikt inny nie umie $w$ ten sposób opowiadać o literaturze.

Spotkań i rozmów z Profesorem było wiele. Wybrałam jego seminarium magisterskie i przez kilka miesięcy jako jedyna uczestniczyłam w tych zajęciach. Przyznaję dziś z uśmiechem, że nie byłam zadowolona, gdy później musiałam podzielić się uwagą Profesora z innymi studentami. Pod jego opieką przygotowałam znaczną część rozprawy doktorskiej. Ze zdumieniem i żalem zauważam, jak wiele jego mądrych słów rozumiem dopiero teraz. Trudno uwierzyć, że nie mam już szansy podzielić się z Profesorem swoimi wątpliwościami.

Profesor zaszczepił we mnie przede wszystkim zainteresowanie twórczością Juliusza Słowackiego. Tu nasze drogi zawsze się spotykały. Zwykł mawiać: „Juliusz Słowacki to ktoś, kogo nie rozumiem”. Z zapałem dociekał tajemnic poety i często przedstawiał swoje interpretacje - tak jak Słowacki - w formie fragmentów, "przyczynków”, ,notatek”, „prób”, , zapisków na marginesie". Mimo skromnej nazwy były one zawsze starannie przemyślane, trafne, „w punkt”, bez zbędnej otoczki. Profesor nauczył mnie ważnej rzeczy - dostrzegania wagi słów. Przestrzegał przed nadmiarem pozbawionym sensu. Wskazywał, jak chwytać istotę rzeczy.

Jego wpływ na moje odczytywanie literatury jest niebagatelny. Zawsze będę patrzeć na tekst trochę jego oczami, mając w głowie pytanie: „Co Profesor by o tym powiedział?". 



\section{$* * *$}

Staliśmy grupą studentów przed salą wykładową dawnego gmachu polonistyki, kiedy pojawił się mężczyzna z siwą czupryną i bystrym wzrokiem, ubrany w czarny polar z nonszalancko zarzuconym plecakiem przez jedno ramię; bezceremonialnie przebił się przez tłum studentów i niemal wbiegł na katedrę. Wyjął pożółkły brulion i książki. Profesor Brzozowski rozpoczął wykład. Choć bardziej trafnym będzie powiedzieć, że Profesor przeniósł nas w świat bohaterów Mickiewicza, Słowackiego, Malczewskiego... Już wtedy poczułam, że zostanę tam dłużej.

Później spotykałam się z Profesorem na seminariach dyplomowych. Każdego z nas traktował indywidualnie, zagrzewał do dyskusji, cierpliwie słuchał i traktował jak równego sobie partnera do rozmowy. Irytował się, kiedy miałam wątpliwości, czy podołam, pielęgnował zuchwalstwo i zapalał do działania. Godzinami rozmawialiśmy o polityce i teatrze. Robił sobie żarty z mojego uwielbienia dla twórczości Lupy, nie zawsze pochwalał moje eksperymenty $\mathrm{w}$ badaniach nad romantyzmem, ale wielokrotnie stawał za mną murem i powtarzał, że gramy do jednej bramki.

Był przy mnie, kiedy stawałam przed komisją egzaminacyjną na studia doktoranckie. Przed rozmową opowiadał anegdoty ze swojego kolokwium doktorskiego i niemal stawał na głowie, żebym nie stresowała się rozmową wstępną. Wierzył we mnie tego dnia bardziej niż ja sama.

Rozczulało mnie jego dbanie o dietę - do kawy zawsze dodawał słodzik i przegryzał wafelek $\mathrm{w}$ czekoladzie. Ten mały rytuał odzwierciedlał jego niepokorność i podkreślał indywidualizm.

Ciągle mam przed oczami Profesora, który pełen emocji przeżywa literaturę, mówi o Mickiewiczu i niemal staje się nim. Już zawsze zostanie moim Profesorem, który z przyjazną ironią komentuje me poczynania. 



\section{Profesor}

\section{Jacek Brzozowski - wspomnienie ucznia}

Katedra Literatury i Tradycji Romantyzmu na łódzkiej polonistyce mieściła się w wysokim i dość ponurym pokoju na trzecim piętrze zabytkowego budynku niemieckiego gimnazjum. Na wystrój sali składały się trzy biurka, sporej wielkości drewniany stół konferencyjny, kilka (nie)umarłych fikusów - utrzymywanych w tym stanie przez Profesora, który, wsypując do nich codziennie popiół z fajki, "chronił je przed mszycami”"1 - oraz wiekowy komputer prowadzący już w pełni autonomiczne wobec pracowników Katedry życie. Jeszcze w początkowym okresie moich studiów pokój ten charakteryzował się ostrą wonią dymu nikotynowego, który narastał po każdym zebraniu pracowników. Podczas pierwszego roku studiów doktoranckich starałem się zadbać nieco o stan powietrza w Katedrze, dlatego przed prowadzonymi przeze mnie konwersatoriami otwierałem okno, siadałem na szerokim przedwojennym parapecie i wypalałem jednego papierosa za drugim, nerwowo oczekując pierwszych zajęć ze studentami. Zarysowany układ przestrzenny pomieszczenia katedry jest niezbędny do ukazania sposobu, w jaki Profesor Brzozowski prowadził nasze seminaria dyplomowe na studiach magisterskich. Mistrz w trakcie owych zajęć siedział u szczytu konferencyjnego stołu, zaś kubek z kawą stawiał zawsze na przeciwległym biurku, ustawionym na drugim końcu sali. Rozmawiając z nami, zrywał się nagle zza stołu, podchodził do oddalonego o kilka metrów kubka z kawą, wypijał kilka łyków i powracał na swoje wcześniejsze miejsce. Ten rytuał powtarzał w ciągu godziny blisko cztery razy. W połączeniu z nieustannym poprawianiem nóg, uderzaniem dłońmi o stół, wstawaniem, siadaniem, nachylaniem się do nas i przechylaniem na krześle dawało to dość dynamiczny układ choreograficzny. Ten swoisty performance był jednak Profesorowi niezbędny, bowiem zawsze wyrażał swoje myśli w ruchu, geście, zmianie postawy. Jak należy więc słusznie domniemywać z tego krótkiego opisu,

\footnotetext{
${ }^{1}$ Wyróżnione cytaty są dosłownymi przywołaniami słów Profesora Brzozowskiego.
} 
jego myśli były równie dynamiczne jak ruchy ciała. Profesor protestował, kładł nacisk, chwalił, oburzał się, a przede wszystkim - zastanawiał się. Prezentowane przez nas referaty rozbierał - niczym pradawny alchemik - na najprostsze elementy i razem z nami próbował sprawdzić je w różnych konfiguracjach. Tworzył przed nami rozmaite struktury i rozgwieżdżone konstelacje, z którymi trzeba było sobie jakoś poradzić. Nie było nam łatwo. Mistrz górował nad nami nie tylko wiedzą, ale przede wszystkim świeżością i rzutkością swojego myślenia. A my staraliśmy się nadążać. Jego seminaria wyrobiły w nas umiejętność szybkiego kojarzenia elementów oraz niezgodę na „oczywiste oczywistości”. Profesor nie mówił nam, jak mamy czytać, myśleć i pisać, ale pokazywał nam to. Byliśmy więc uczniami Czarnoksiężnika. Jako jego adepci przeszliśmy przez kolejne kręgi wtajemniczenia: naukę o najdrobniejszych elementach dzieła literackiego, żywiołach twórczych, o możliwych konstelacjach interpretacyjnych. Po przejściu tych pierwszych stopni poznania przyszła próba najcięższa - próba tekstu. Profesor odsyłał nam nasze tak przecież pieczołowicie przygotowywane referaty i rozdziały prac magisterskich z piętrzącymi się sugestiami poprawek. Nie były to jednak łatwe do rozszyfrowania komentarze na marginesie. Mistrz wyróżniał źle napisane zdanie ciemniejszą czcionką i podkreśleniem. Do nas należało odszyfrowanie, czy zdanie jest błędne pod względem gramatyki, stylu bądź sensu. Jeżeli mieliśmy problem z interpretacją intencji Mistrza, zapraszał nas na konsultacje i tłumaczył, co dokładnie wymaga poprawek. Z czasem nauczyliśmy się odczytywać jego uwagi. Patrząc z pewnego dystansu, muszę przyznać, że był to świetny sposób nauki krytycznej lektury własnych tekstów. Profesor wiedział, że nie może nas przeprowadzać za rękę przez kolejne kręgi naukowego wtajemniczenia, że powinien nam jedynie wskazać drogę. I tak robił, ujawniając przed nami pułapki, jakie sami stawialiśmy przed sobą w naszych tekstach. Kazał nam je samodzielnie rozpoznać, nazwać i oswoić po to, byśmy nigdy więcej nie błądzili. Z czasem podkreśleń i wyróżnień było mniej... choć i tak wciąż za dużo. Nieustannie podziwiałem jego cierpliwą wnikliwość, z jaką czytał każdą moją pracę. Warto również dodać, że Profesor nie kazał nam długo czekać na swoje poprawki. Odsyłał je błyskawicznie - niekiedy nad ranem.

Po okresie studiów magisterskich nadszedł czas doktoratu. Tuż przed naborem na studia trzeciego stopnia spotkałem się z Mistrzem i, bojąc się odpowiedzi, spytałem, czy zgodzi się być moim promotorem. Profesor spojrzał na mnie uważnie i powiedział, że „doktorat doktoratem, ale najpierw trzeba przejść przez rozmowę przed komisją wydziałową. Ja z Panem tam oczywiście pójdę - będzie się Pan czuł bezpiecznie". Moje następne wspomnienie dotyczy oczekiwania na wspomnianą rozmowę. Siedziałem na korytarzu wraz z kolegami z pozostałych kierunków filologicznych, niezbyt cierpliwie oczekując, aż zostanie wywołane moje nazwisko. W trakcie nerwowego monologu wewnętrznego, podczas którego przypominałem sobie najważniejsze tezy planowanej rozprawy doktorskiej, zauważyłem znajomą sylwetkę dynamicznie zbliżającą się w moim kierunku. Profesor podszedł, 
przywitał się, po czym stanął, spoglądając na mnie uważnie. Gdy zauważył, że jestem zestresowany zbliżającą się z rozmową z władzami Wydziału, pocieszył mnie - „Panie Mateusz, to przecież formalność”. I nagle, ten niegdysiejszy Mistrz i Promotor, uśmiechnął się, a w jego oczach zapłonęły figlarne ogniki. Przeskakując z nogi na nogę (Profesor - jak już wspominałem - zawsze pozostawał w ruchu), zaczął przywoływać anegdotę o pewnym przedstawieniu, wystawianym w Instytucie Badań Literackich. Opowieść ta ma dość figlarny charakter, więc zachowam jej szczegóły w tajemnicy. Istotne jest, jak Profesor ją przedstawił. Wcielając się w bohaterów snutej anegdoty, parodiował ich ruchy, gestykulował, naśladował sposób chodzenia, śmiejąc się do rozpuku. Jego śmiech okazał się zaraźliwy dla niemal wszystkich znajdujących się w naszym sąsiedztwie. Performance w wykonaniu Mistrza spełnił swoje zadanie - trawiący mnie wcześniej stres ustąpił wesołości. Po rozmowie przed komisją, gdy wyszliśmy z sali, Profesor pożegnał się ze mną, dodając: „No, wcale nieźle, Panie Mateuszu”. Dla każdego, kto kiedykolwiek współpracował z Profesorem Brzozowskim, ta - wydawałoby się - dość oszczędna pochwała była wyrazem najwyższego uznania.

Dwa lata później pojechaliśmy wspólnie na organizowaną w Toruniu sesję poświęconą twórczości Cypriana Norwida. Na plenarnych obradach nas obu trawił nieznośny kaszel. Poważna konferencja, autorytety z dziedziny badań norwidologicznych wygłaszają referaty, a my obaj nieustannie zanosimy się kaszlem. W pewnym momencie, gdy ja skończyłem swoją partię solową, Profesor - wyraźnie rozbawiony - zauważył, że w sumie to z tego wspólnego kaszlenia można by nagrać „wcale ciekawy koncert”. Mój brak dyspozycji na wspomnianym sympozjum związany był z nasilającym się zapaleniem oskrzeli. Kaszel Profesora - suchy i głęboki - był niestety oznaką już wtedy rozwijającej się śmiertelnej choroby. Mistrz, całkowicie nieświadomy tego faktu, podczas obrad i kolacji pozostawał w wyśmienitym oraz skorym do żartów nastroju. W trakcie wieczornego spotkania zamykającego pierwszy dzień obrad poskarżył się jednemu z profesorów na zepsuty zamek błyskawiczny w swym legendarnym czarnym polarze. Zirytowany dodał z rezygnacją, że niestety będzie musiał wyrzucić okrycie. Jego rozmówca, słysząc te słowa, zamyślił się, po czym refleksyjnym tonem, troskliwie ujmując zepsuty ekspres, zauważył: „Szkoda takiego zasłużonego dla nauki polskiej polara...". Profesor Brzozowski, nieco onieśmielony, machnął ręką, kwitując te słowa z wrodzoną sobie skromnością: „Daj spokój, mam jeszcze dwa identyczne”. Nie wiem, jaki los podzieliło „zasłużone dla nauki polskiej" okrycie, ponieważ później zawsze widywałem Profesora w czarnym polarze, z podwiniętymi rękawami, które dawały słuszne wrażenie, że Mistrz zaraz zabiera się do trudnej i wymagającej precyzji pracy.

W trakcie obrad konferencyjnych Profesor pełen zapału komentował poszczególne referaty, uzupełniając je wrażeniami z meczu piłki nożnej, oglądanego w pokoju hotelowym. Dyskutowaliśmy również o naszych interpretacjach Pierścienia Wielkiej Damy Norwida. Jak zawsze, nie zgadzaliśmy się $\mathrm{w}$ naszych odczytaniach. Podobnie było w trakcie już ostatniego 
półrocza moich studiów doktoranckich, kiedy oddałem Profesorowi ukończoną drugą część dysertacji. Późnym wieczorem przesłał mi mail z redakcyjnymi wskazówkami. Dotyczyły one głównie językowej warstwy rozprawy, choć zawierały również uwagi odnoszące się do mojego odczytania Romantyczności. Mistrz zajmował się tym tekstem, pisząc - w mojej opinii - kanoniczną interpretację ballady Mickiewicza. Następnego dnia, po dziesiątej rano, usłyszałem dzwoniący telefon. Profesor chciał doprecyzować swoje uwagi, zaznaczając, że zaproponowana przeze mnie lektura utworu Mickiewicza jest dalece ryzykowna i w zasadzie "podkładam się pod ostrze krytyki recenzentów". To był długi, niezwykle dynamiczny monolog, podczas którego Profesor zapewne chodził po pokoju, gestykulując i raz za razem zaglądając do mojej rozprawy. Umówiliśmy się na rozmowę podczas jego konsultacji. Dwa tygodnie później spotkaliśmy się u niego w gabinecie. Profesor - trawiony już wtedy chorobą i zmęczony prowadzonym wcześniej wykładem - nasypał kawy do kubka prosto z plastikowego opakowania (nigdy nie używał do tej czynności łyżeczki), nalał do naczynia na zmianę gorącą i zimną wodę, po czym usiadł. Gwałtownie wypił napój, jakby chcąc ukryć zmęczenie. Już wtedy byłem świadom, że to może być jedna z naszych ostatnich rozmów. Siedząc naprzeciwko Profesora, powiedziałem, że zgadzam się z jego krytyką, ale mimo wspomnianego ryzyka pragnę pozostać przy takim kształcie interpretacji, jaką mu przysłałem. „Dobrze, Panie Mateuszu - to pański tekst. Proszę tylko ubezpieczyć się przed uwagami recenzentów. Wie Pan, o co chodzi". Wiedziałem. Profesor, widząc to, dodał tylko: „doskonale". Była to jedna z ostatnich naszych rozmów. Jeżeli jakiś jej element najbardziej zapadł mi w pamięć, to głos Mistrza - cichy, nieco chropowaty. Stanowił on całkowite przeciwieństwo siły i głębokości, jakie pamiętałem z poprzednich rozmów. Niemniej, pozostał jeden charakterystyczny element, który nie uległ zmianie. Choć jego głos był cichy i zmęczony, to wciąż zachowywał w sobie pewność i stanowczość. Choroba nie mogła pozbawić Profesora jego wewnętrznej siły, pierwiastka energicznej i dynamicznej osobowości.

Już po Jego śmierci redagowałem ostatnie fragmenty rozprawy doktorskiej. Bardzo często, czytając i poprawiając tekst, słyszałem w uchu głęboki i pewny swej racji głos Profesora: „Panie Mateuszu, to zdanie jest zbyt jajowe. Niech Pan to poprawi”, albo: „To mogłoby być napisane - no wie pan - bardziej chlujnie". To dowód na to, jak wiele Mu zawdzięczam oraz jak duży zaciągnąłem u niego dług. Dług, który może uda mi się kiedyś spłacić. 


\section{Mistrzowskie pastisze Jacka Brzozowskiego, czyli wspomnienie nocy sylwestrowej z przełomu 2004 i 2005 roku}

Jacek Brzozowski był jednym z najwybitniejszych (i od razu dodać trzeba: najsubtelniejszych) interpretatorów liryki romantycznej i współczesnej, to oczywiste dla każdego znawcy rodzimej literatury. Pewnego razu zdarzyło się, że poznałem też Jego niebywałą biegłość w sztuce trawestowania, "pastiszowania" tekstów poetyckich, i to tych z najwyższej półki, o czym kilka słów za chwilę. Zawsze, przez wszystkie lata akademickiej dydaktyki, nieodmiennie zobowiązywałem studentów do poznawania Jackowego „odczytywania romantyków”, wykładni wierszy Mickiewicza, Słowackiego, Norwida i z upodobaniem wykorzystywałem je na seminariach, konwersatoriach, przy okazji wykładów. I ten stan rzeczy nie zmieni się, choć trudno oswoić się z myślą, że nowych lektur Jacka już nie będzie.

Jacek Brzozowski związany był z poznańskim środowiskiem akademickim wielorakimi więzami, pisywał recenzje doktorskie naszym wychowankom, chętnie przyjeżdżał na poznańskie konferencje, czasem brał udział w zebraniach Zakładu Literatury Romantyzmu. Ze swoim przyjacielem Zbyszkiem Przychodniakiem, profesorem z Instytutu Filologii Polskiej UAM, stworzył znakomitą „spółkę edytorską", w ramach której powstały nowatorskie i odkrywcze edycje dzieł Słowackiego: wierszy i poematów, z osobnym rewelacyjnym (niewątpliwe arcydzieło edytorskie!) wydaniem poematu Beniowski, tomy te ogłaszali w Wydawnictwie Naukowym UAM, z którym Jacek, jako autor i recenzent, blisko współpracował, tu ogłosił między innymi świetną monografię Odczytywanie romantyków (2). Czekaliśmy na ich edycję Króla-Ducha, spodziewając się równie odkrywczego dzieła edytorskiego jak w przypadku Beniowskiego... W czerwcu 2017 roku, kilkadziesiąt godzin po śmierci Jacka, na zebraniu Rady tego wydawnictwa przedstawiałem Jego 
ostatnią recenzję, napisaną $\mathrm{w}$ maju, a poświęconą książce zbiorowej, dedykowanej pamięci zmarłego w styczniu tego roku profesora Józefa Tomasza Pokrzywniaka, i w tamtej chwili, w tym nieoczekiwanym związku przedwczesnych zgonów dwu wybitnych badaczy, kryła się jakaś trudna do nazwania, poruszająca symbolika egzystencjalno-żałobna.

Jacek był mistrzem $\mathrm{w}$ posługiwaniu się (auto)ironią, miał świetne poczucie humoru i z tego względu był też przeuroczym kompanem w sytuacjach towarzyskich, choć potrafił też formułować zdecydowane sądy i opinie, na przykład polityczne, tak się zresztą składało, że w tej sferze bodaj mieliśmy bardzo zbliżone poglądy. Jacek z niechęcią przyjmował wszelkie przejawy myślenia autorytarnego, ksenofobicznego, nacjonalistycznego, był, jak się wydaje, przywiązany do idei popperowskiego „społeczeństwa otwartego", nie lubił więc jego wrogów... Raz wszelako zaskoczył mnie talentem, o którego istnieniu nie wiedziałem.

Zdarzyło się to w Sylwestra roku 2004, który spędziliśmy w gościnnym domu Marii i Zbyszka Przychodniaków w Puszczykowie, koło Poznania, w gronie kilkorga akademików, w gronie gości byli także Ewa i Jacek Brzozowscy. Wśród różnych zadań, jakie nałożyliśmy na siebie przed tą imprezą, było przygotowanie pastiszów lub trawestacji dzieł literackich, a turniejowa prezentacja owych prób miała być jednym z centralnych wydarzeń wieczoru. I była, choć w zgodnej opinii Jacek stłamsił wszystkich konkurentów, prezentując - i mistrzowsko odczytując - zbiór, a właściwie cykl siedmiu kapitalnych, superdowcipnych przeróbek słynnych wierszy Mickiewicza, Słowackiego, Krasińskiego, Norwida, Herberta i Szymborskiej. Ułożył je w błyskotliwy "cykl kulinarny”, dając jednocześnie dowód fenomenalnego wyczucia dykcji poetyckiej trawestowanych arcytwórców. Wydaje mi się, że tekstów tych nigdy nie opublikował, choć zapewne i przy innych okazjach je odczytywał. Tu chciałbym „oddać je światu” (za zgodą Gospodarza tamtego Sylwestra) w wersji, w jakiej je wtedy, na przełomie 2004 i 2005 roku, Jacek nam ofiarował... 


\section{Biesiada grudniowa, Pięć li-ryków z trzema epilogami ${ }^{1}$}

Ej! ty na szybkim koniu gdzie pędzisz, kozacze?

Do karczmy, me pacholę, gdzie czeka Prosiaczek!

Antoni Malczewski, Ochmistrzyni Maria. Powieść obyczajowa

I

\section{Adam Mićkiewicz}

\section{Dziady. Poema fantastyczne}

(zaniechany rzut początku sceny II)

Folwark zwierzęcy opodal Wilna - dawna rezydencja dziadów hrabiego Lita-wora - sypialnia Józia i Rózi zamieniona na jadalnię - wielki okrąły stót - bije dziewiąta - wśrodku Porcellus, sam

\section{Gustavus Conradus Porcellus \\ (po dtugim chrumkaniu)}

Samotność - cóż po ludziach, czym prosiak dla ludzi?

Gdzie człowiek, co z mych tkanek wewnętrzną treść wyniucha,

${ }^{1}$ Kilka spośród zebranych tu tekstów powstało w związku z obchodzonym w początkach 2001 roku jubileuszem dwudziestolecia Katedry Literatury Romantyzmu i Literatury Współczesnej UŁ (kierowanej przez prof. dr hab. Krystynę Poklewską). Rocznicowe spotkanie wieńczyła biesiada w Klubie Spadkobierców (przy Piotrkowskiej 77 w Łodzi), podczas której zostało podane pieczone prosię. Wcześniej pracownicy oraz doktoranci Katedry odbyli kilkugodzinne zebranie naukowe poświęcone jedzeniu w literaturze; wtedy też po raz pierwszy zostały odczytane niektóre z zamieszczonych tu pastiszy. 
Obejmie smakiem całą tłustość mego ducha?

Nieszczęsny, kto dla innych w chlewiku się trudzi:

Wygląd kłamie smakowi, a smak chuciom kłamie;

Chuć z oczu leci bystro, nim się w ustach złamie,

A usta chuć pochłoną i tak drżą nad chucią,

Jak żarłok pochylony nad deserów rzeką.

Z jego drżenia czyż ludzie głąb pragnień docieką,

Gdzie zmierza, czy się nauczą? -

\section{II}

\section{Adam Mićkiewicz-Ciastowski}

Do Józefa Słowiczka. O pieczystym u Andrzeja Towiańskiego (z odnalezionego listu)

Prosiaczku mój! a piecz się, piecz!

Na pożegnanie piecz

Bezmięsnym dniom, łakomym snom

I pustym brzuchom precz!

Prosiaczku mój! cierpliwie stój,

Dojrzałe jabłko weź

I w ostrzu kłów biesiado-snów

Aromat nam tu nieś!

Bo padł już los i pachnie sos,

I tłuszczu biały puch

Tak nęci nas, że natychmiast

Widelce idą w ruch.

\section{III}

Juliusz Euzebiusz herbu Leliwa Słowacki (zw. Anhelli)

Prosiaczki stoja na biesiadnych stołach...

(z albumu rysunkowego dla JO Księcia Radziwiłła Sierotki)

Prosiaczki stoją na biesiadnych stołach

I - chcąc powitać - pachną przerozkosznie,

A my - zebrani spolnie - dookoła

Patrzymy na nie - i apetyt rośnie.

A one stoją w rumianości harde

I... tak... się proszą o nóż i musztardę. 
„Postój, o postój, biesiadniku skory!

Przez co to sięgasz prosięcego boku?".

"To nic... to tylko są ducha humory,

W trzewiach mię ściska, łza się kręci w oku".

Prosiak nie strzymał, podniósł się z talerza...

Wypuścił jabłko... w stronę wyjścia zmierza...

IV

\section{Zygmunt Krasiński (właść. Henryk Spirytualion Mielikowski)}

Bóg mi odmówił...

(wiersz zapisany na odwrocie recepty na laudanum)

Bóg mi odmówił tej zwyczajnej miary,

Bez której nie ma co do stołu siadać;

Gdybym ją posiadł, piłbym tokaj stary,

A że jej nie mam, muszę postnie jadać.

Ach, w trzewiach moich są tajne pragnienia,

Lecz nim ust dojdą, łamią się na dwoje;

Ludzie nie słyszą nic okrom burczenia,

Ja dniem i nocą słyszę głody moje.

One tak biją na krwi mojej falach,

Jak gwiazda, brzmiąca na wirach błękitu;

Ludzie nie słyszą ich po mlecznych barach,

Mój kucharz słyszy od zmroku do świtu.

\section{V}

Cyprian Norwid, kawaler Pierścienia Wielkiej Damy

\section{Z wstęp (Jadłospisiki)}

(z niewydanego tomu Vademecum kucharza doskonatego)

1

Gdy, z wiosną życia, Sybaryta

Poi się obfitością stoła,

Wolno mu tylko tyle wołać:

„Nie ma jak tucz i okowita!". 
Lecz gdy późniejszych chorób dreszcze

Ciałem wzruszą - i smak z-tępieje -

Wtedy dodawać trzeba jeszcze:

"Najlepsze to jest - co się nie je...".

3

Ponad wszystkie wasze pragnienia -

Ty! żołądku, i ty, o gardło -

Jedna rzecz się nigdy nie zmienia:

$+++++++$

Odpowiednie dać sobie jadło!

\section{Epilog I}

\section{Wisława z Krakowa}

Dwie świnki. Słowiański sen hodowcy Piotra B. $z$ Antwerpii

(wiersz odnaleziony w pracowni Jana Styki)

Tak wygląda mój wielki gospodarski sen:

siedzą w chlewie dwie świnki nad pustym korytem,

na progu sterta śmieci

i błoto po pas.

Wchodzę z cebrzykiem pomyj,

po kolana brnę.

Świnka, zwrócona do mnie, ironicznie zerka, druga w błocie ukryta -

a kiedy już pomyje wlałem do koryta,

chrząknie nerwowo:

„Piotrze, nie myłeś ceberka”.

\section{Epilog II}

\section{Zbigniew Patryk Herbert Herczyński}

\section{Dlaczego magnetyzm}

(z tomu Napis, Apis i Jadłospis)

\section{1}

W czterdziestym czwartym fragmencie 365 obiadów

Lucynna Quadrans opowiada dzieje swojej nieudanej potrawy 
pośród długich przepisów

pieczeń gotowań smażeń

gęstej masy budyniu

kulinarnych specjałów

epizod ten jest jak ziarnko ryżu

$\mathrm{w}$ pomidorowej z ryżem

delegacja hodowców z Aten

poszła do innej tawerny

ponieważ Lucynna spóźnił się z prosiakiem

zapłacił za to właścicielowi

dozgonnym bezrobociem

\section{2}

kucharze ostatnich czasów

jeśli zdarzy im się podobna afera

skomlą na kolanach przed biesiadnikami

zachwalają swoje mistrzostwo

i niewinność

oskarżają kuchcików

zawistnych kolegów

jakość węgla i gazu

Lucynna mówi tylko

że miał mało czasu

był sam

i piekł szybko

3

jeśli powodem wyjścia

ma być samotny kucharz

który robi co może

nad surowym prosiakiem

to ja wolę magnetyzm

niechby był i zwierzęcy

bo mi daje nadzieję

że kucharz w końcu dopiecze

\section{Epilog III}

\section{prywatny}

Uciec z tuszą na stryszek i jak kuchcik szukać tam wina i dzieweczki - 



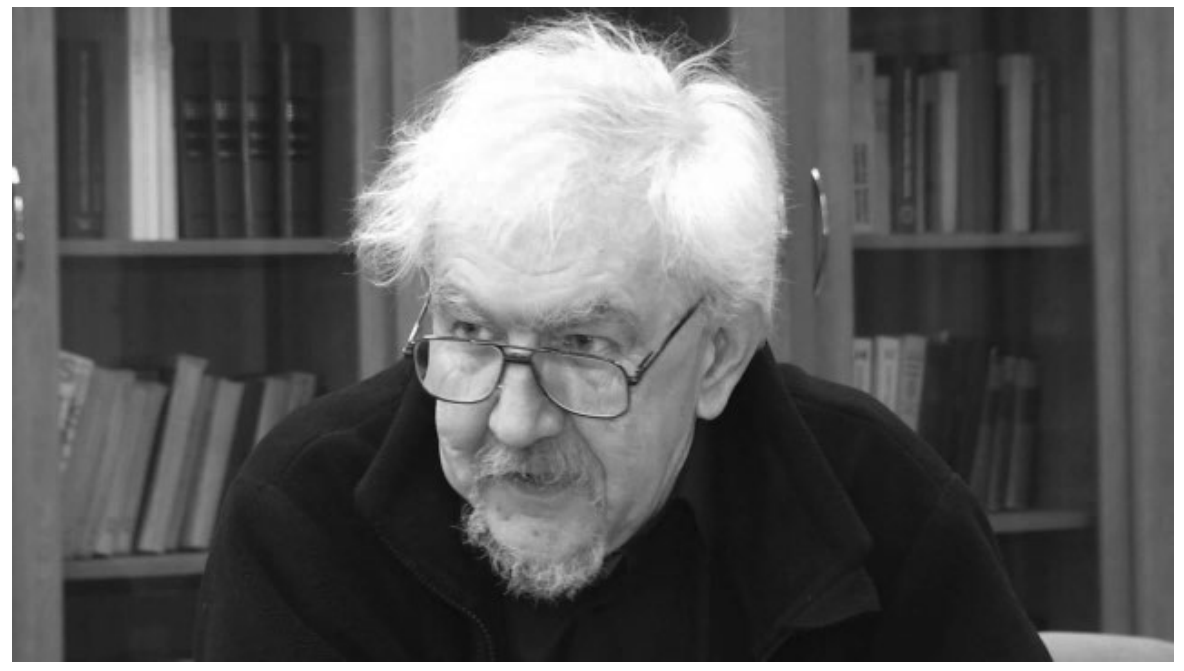

Prof. Jacek Brzozowski podczas udzielania wywiadu dla studenckiej telewizji Uniwersytetu Łódzkiego o pierwszym wydaniu wyboru wierszy Juliusza Słowackiego przez Wydawnictwo Ossolineum w serii „Biblioteka Narodowa” (marzec 2014 roku) 



\section{Dorobek
Profesora Jacka Brzozowskiego}

\section{Książki}

Muzy w poezji polskiej. Dzieje toposu do przełomu romantycznego, Wrocław 1986. „Pan Cogito" Zbigniewa Herberta, Warszawa 1991, seria: „Moje Lektury”.

Odczytywanie znaczeń. Studia o poezji Mickiewicza, Łódź 1997.

K. Poklewska, J. Brzozowski, O Mickiewiczu i Słowackim. Cztery szkice, Łęczyca 1999.

Odczytywanie romantyków. Szkice i notatki o Mickiewiczu, Malczewskim i Stowackim, Kraków 2002.

Późne wiersze poetów polskich XX wieku. Dwanaście szkiców i komentarzy, Łódź 2007.

Odczytywanie romantyków (2). Dwadzieścia dwa szkice i notatki o Mickiewiczu, Słowackim i Norwidzie, Poznań 2011.

11 szkiców o czytaniu wierszy, Łódź 2013.

Parerga edytorskie. (Z prac nad tekstami Juliusza Słowackiego), Łódź 2013.

\section{Książki - redakcja}

Zaczynajac od Miłosza... Antologia wierszy - dla licealistów, oprac. J. Brzozowski, A. Kowalczykowa, Warszawa 1993.

Dlaczego Różewicz. Wiersze i komentarze, red. J. Brzozowski, J. Poradecki, Łódź 1993.

O wierszach Mirona Białoszewskiego. Szkice i interpretacje, red. J. Brzozowski, Łódź 1993.

O wierszach Wistawy Szymborskiej. Szkice i interpretacje, red. J. Brzozowski, Łódź 1996.

„Prace Polonistyczne” LII, Studia i szkice o Stowackim, red. J. Brzozowski, Łódź 1997.

Wiersze Adama Mickiewicza. Analizy, komentarze, interpretacje, red. J. Brzozowski, Łódź 1998. 
Szkice o poezji Aleksandra Wata, red. J. Brzozowski, K. Pietrych, Warszawa 1999.

Rozjaśnianie ciemności. Studia i szkice o Norwidzie, red. J. Brzozowski, B. Stelmaszczyk, Kraków 2002.

„Prace Polonistyczne" LVIII, Romantycy - fantastyka - podróż, red. J. Brzozowski, B. Stelmaszczyk, Łódź 2003.

Mickiewicz czytany w szkole. Materiały konferencji naukowej nauczycieli [Łódź 23-25 września 2005], red. J. Brzozowski, K. Pietrych, Łódź 2007.

Stolice i prowincje kultury. Księga jubileuszowa ofiarowana prof. Alinie Kowalczykowej, red. J. Brzozowski, M. Skrzypczyk, M. Stanisz, Warszawa 2012.

Strategie "ja" (po)romantycznego w poezji polskiej XIX-XXI, cz. 1: Studia i szkice, cz. 2: Rozmowy, red. J. Brzozowski, K. Pietrych, Łódź 2017.

\section{Edycje}

Słowacki J., Wiersze. Nowe wydanie krytyczne, oprac. J. Brzozowski, Z. Przychodniak, Poznań 2005.

Słowacki J., Poematy. Nowe wydanie krytyczne, t. 1: Poematy z lat 1828-1839, t. 2: Poematy i fragmenty z lat 1842-1849, oprac. J. Brzozowski, Z. Przychodniak, Poznań 2009.

Słowacki J., Dziennik z lat 1847-1849. Podobizna autografu, transliteracja, transkrypcja, komentarz edytorski, objaśnienia, oprac. J. Brzozowski, K. Szumska, Wrocław 2012.

Słowacki J., Wiersze, oprac. J. Brzozowski, Z. Przychodniak, Wrocław 2013. Słowacki J., Beniowski. Poemat z roku 1841 i dalsze pieśni, oprac. J. Brzozowski, Z. Przychodniak, Poznań 2014.

\section{Artykuły}

O symbolizmie "środka” i tragicznej wizji świata Tadeusza Różewicza, „Prace Polonistyczne" XXXIII, 1977.

Krótka historia zwierząt, które także bywają śmiertelne, „Teksty” 1979, nr 6.

Szkic do analizy tematycznej twórczości Tadeusza Różewicza, "Acta Universitatis Lodziensis. Folia Litteraria" 1, 1981.

Antyk Herberta, [w:] Topika antyczna w literaturze polskiej XX wieku, red. A. Brodzka, E. Sarnowska-Temeriusz, Wrocław 1992; także w: Poznawanie Herberta 2, wybór i wstęp A. Franaszek, Kraków 2000.

Mieszkaniec krainy bez światta. Wokót wiersza *** Einst hab ich die Muse gefragt...,

[w:] Dlaczego Różewicz. Wiersze i komentarze, red. J. Brzozowski, J. Poradecki, Łódź 1993.

Milczenie Mickiewicza, „Miscellanea Łódzkie” 1993.

Glosy do „Romantyczności”, „Prace Polonistyczne” XLIX, 1994.

W strone Lozanny. Wistawy Szymborskiej czytanie Mickiewicza, „Rocznik Towarzystwa Literackiego imienia Adama Mickiewicza" 1996. 
Uwagi, dla których powodem byt wiersz "Daje wam tę ostatnią koronę pamiątek...", „Prace Polonistyczne" LII, 1997.

O mickiewiczowskich diabłach w ogólności, „Teatr” 12, 1997.

Miron Biatoszewski: "namuzowywanie" i "muźnięty”, [w:] Poezja wspótczesna w szkole. Interpretacje, red. A. Kowalczykowa, Warszawa 1998.

Zbigniew Herbert: „Brak węzła”, [w:] Poezja wspótczesna w szkole. Interpretacje, red. A. Kowalczykowa, Warszawa 1998.

O dwóch wieczorach autorskich Wistawy Szymborskiej, „Acta Universitatis Lodziensis. Folia Litteraria Polonica" 1, 1998.

O „Hugonie”, ,Rocznik Towarzystwa Literackiego imienia Adama Mickiewicza" 1999.

Charles Baudelaire: „Albatros", [w:] Zaczynajac od Baudelaire'a. Interpretacje, red. A. Kowalczykowa, T. Marciszuk, Warszawa 1999.

Baczyński w biaty dzień. O wierszu Wistawy Szymborskiej, [w:] Krzysztof Kamil Baczyński. Twórczość, legenda, recepcja, red. J. Detko, Kielce 2002; "Zeszyty Szkolne" 2002, nr 4.

Antik in 18. und 19. Jahrhundert, [w:] Der neue Pauly Enzyklopädie der Antike, t. 15/2, red. H. Cancik, H. Schneider, Stuttgart-Weimar 2002, s. 396-397.

Trzy domysty na marginesie wiersza "Snuć mitość...", „Prace Polonistyczne" LVIII, 2003.

O wierszu „Uprzejmość niewidomych" Wisławy Szymborskiej, "Zeszyty Szkolne" 2004, nr 3; też w: Wistawa Szymborska. Tradice - součastnost - recepce. Materiály $z$ mezinárodní vědecké konference uskutečněné v Ostravě ve dnech 4.-5. prosince 2003 u príležitosti 80. narozenin Wistawy Szymborské, red. M. Balowski, J. Raclavská, Ostrawa 2004

Kilka uwag o rysunkach Stowackiego, „Prace Komisji Filologicznej/Poznańskie Towarzystwo Przyjaciół Nauk" 2008, t. 54.

"Dawniej myślatem rzeczy uczynić szalone...". Kilka uwag o idei "Dziet zebranych" Juliusza Stowackiego, „Wiek XIX: Rocznik Towarzystwa Literackiego imienia Adama Mickiewicza" II, 2009.

Nad wierszem "Anioł ognisty - mój anioł lewy...". O kilku problemach edytorskich, „Pamiętnik Literacki” 2009, z. 3.

Dwa zapomniane rysunki Juliusza Stowackiego, „Pamiętnik Literacki” 2009, z. 3.

Brzozowski J., Przychodniak Z., Niezwykty przypadek "zniszczonego" autografu: o tzw. rękopisie warszawskim "Odpowiedzi na «Psalmy przysztości»" Juliusza Stowackiego, „Pamiętnik Literacki” 2009, z. 4.

Notatki do lektury wierszy Juliusza Stowackiego, "Czasopismo Zakładu Narodowego Imienia Ossolińskich" 2010, z. 20/21.

Dwie redakcje "Świąt przyszłych narodowych" Juliusza Stowackiego, „Pamiętnik Literacki" 2011, z. 1.

Jarostawa Iwaszkiewicza wiersz „pośmiertny”, „Czytanie Literatury” 2012.

Notatki na marginesie dwóch wierszy Tadeusza Różewicza, "Czytanie Literatury" 2013.

Uwagi o tomach trzecim i czwartym "Dzieł wszystkich" Cypriana Norwida, "Studia Norwidiana" 2014. 
Brzozowski J., Fradois E., Kalinowska M., Przychodniak Z., Odnaleziony autograf francuskiego wiersza Juliusza Stowackiego, „Pamiętnik Literacki" 2014, z. 2.

Trzy notatki o miejscach i tematach wartych do-czytania, „Acta Universitatis Lodziensis. Folia Litteraria Polonica" 1, 2015.

\section{Recenzje}

[Recenzja książki Jana Błońskiego, Odmarsz, Kraków 1978], „Pamiętnik Literacki" 1980, z. 4.

[Recenzja książki Stanisława Beresia, Uwięziony w śmierci. O twórczości Tadeusza Gajcego, Warszawa 1992 oraz tomu: Tadeusz Gajcy, Wybór poezji. Misterium niedzielne, oprac. Stanisław Bereś, Wrocław-Warszawa-Kraków 1992, BN I 283], „Pamiętnik Literacki” 1994, z. 1.

Laudacja z okazji ukończenia edycji rocznicowej "Dziet” Adama Mickiewicza [t. I-XVII, Warszawa 1993-2005], „Rocznik Towarzystwa Literackiego Imienia Adama Mickiewicza" XLI/2006, Warszawa 2007, s. 114-118.

[Recenzja edycji dzieł Adama Mickiewicza, Dzieła. Wydanie Rocznicowe, red. naczelna: Z.J. Nowak, M. Prussak, Z. Stefanowska, C. Zgorzelski, t. 1-17, Warszawa 1993-2005], „Pamiętnik Literacki” 2009, z. 4.

\section{Inne}

Wielkie dzieła literatury polskiej. Leksykon, PRO-Media CD, Łódź 1997 [biogramy: Aleksander Fredro, Zbigniew Herbert, Jan Kasprowicz, Jan Lechoń, Bolesław Leśmian, Antoni Malczewski, Adam Mickiewicz, Jan Andrzej Morsztyn, Cyprian Norwid, Leopold Staff, Mikołaj Sęp Szarzyński, Stanisław Trembecki, Julian Tuwim, Tadeusz Żeleński (Boy); hasła: Aleksander Fredro: Pan Jowialski, Śluby panieńskie, Trzy po trzy, Zemsta; Zbigniew Herbert: Pan Cogito; Jarosław Iwaszkiewicz: Oktostychy; Jan Kasprowicz: Hymny, Ksiegga ubogich, Mój świat; Jan Lechoń: Karmazynowy poemat; Bolesław Leśmian: Łąka; Antoni Malczewski: Maria; Adam Mickiewicz: Ballady i romanse, Dziady (II, IV, III), Konrad Wallenrod, Ksiegi narodu polskiego i pielgrzymstwa polskiego, Pan Tadeusz, Sonety krymskie, liryki lozańskie; Jan Andrzej Morsztyn: Kanikuła, Lutnia; Cyprian Norwid: Pierścień Wielkiej Damy, Promethidion, Vade-mecum; Juliusz Słowacki: Beniowski; Leopold Staff: Sny o potędze, Wiklina, Wysokie drzewa; Mikołaj Sęp Szarzyński: Rytmy abo wiersze polskie; Stanisław Trembecki: Sofiówka; Julian Tuwim: Bal w Operze, Kwiaty polskie; Tadeusz Żeleński (Boy): Stówka].

"Z poetyckiego zaklęcia i gusta...". Sonety, red. J. Brzozowski, J. Sikorzanka, Łódź 1999.

"Lecz wspomnienia nie zetra w popiót obce świty...". Wiersze sztambuchowe, red. J. Brzozowski, J. Sikorzanka, Łódź 2000.

„Uff, więc się nie skończyt świat...". Fraszki na koniec wieku, red. J. Brzozowski, J. Sikorzanka, Łódź 2001. 
„Wszystko to być może...". Bajki, red. J. Brzozowski, J. Sikorzanka, Łódź 2002. „a tam Mistrz Miron czeka...". Wiersze à la Miron, red. J. Brzozowski, J. Sikorzanka, Łódź 2003.

„Raz pewnemu mężowi z Krakowa...". Limeryki, red. J. Brzozowski, J. Sikorzanka, Łódź 2004.

Ptynie sobie rzeka. Wiersze dzieci i dla dzieci, red. J. Brzozowski, J. Sikorzanka, Łódź 2005.

Strużka piasku w klepsydrze... Haiku, red. J. Brzozowski, J. Sikorzanka, Łódź 2006.

"więc kiedy już ust sennych otworza się raje...". Wiersze mitosne, red. J. Brzozowski, J. Sikorzanka, Łódź 2007.

"Oto wtaśnie ballada, która o tym opowiada...". Ballady, red. J. Brzozowski, J. Sikorzanka, Łódź 2008.

Pan Cogito po latach. 19 wierszy, red. J. Brzozowski, J. Sikorzanka, Łódź 2009.

"Przeczytaj dopiero, gdy będziesz się do mnie wybierać". Listy poetyckie, red. J. Brzozowski, J. Sikorzanka, Łódź 2010.

„Dziewczyneczki, koroneczki, muślinowych firan ruch...". Oktostychy, red. J. Brzozowski, J. Sikorzanka, Łódź 2011.

"Rzeczy nie dzieją się bez rytmu...". Piosenki, red. J. Brzozowski, J. Sikorzanka, Łódź 2012.

\section{STRESZCZENIE}

Teksty i materiały bibliograficzne, zamieszczone w tym dziale, prezentują sylwetkę i dorobek naukowy prof. dr hab. Jacka Brzozowskiego, wybitnego literaturoznawcy i edytora z łódzkiej polonistyki, zmarłego 18 czerwca 2017 roku.

\section{SUMMARY}

Texts and bibliographical materials included in this section, present the figure and scientific achievements of prof. dr hab. Jacek Brzozowski, an outstanding literary scholar and editor of the polish language studies in Lodz, who died on June 18, 2017. 